\title{
COPING WITH DISASTERS: \\ TWO CENTURIES OF INTERNATIONAL OFFICIAL LENDING
}

\author{
Sebastian Horn \\ Carmen M. Reinhart \\ Christoph Trebesch \\ Working Paper 27343 \\ http://www.nber.org/papers/w27343 \\ NATIONAL BUREAU OF ECONOMIC RESEARCH \\ 1050 Massachusetts Avenue \\ Cambridge, MA 02138 \\ June 2020
}

We thank Erik Eichler, Leonard Rosen and Robert Yee for excellent research assistance as well as the German Research Foundation (DFG) for financial support (SPP 1859). Sebastian Horn gratefully acknowledges financial support from the Egon Sohmen Graduate Center at LMU Munich. We thank Harold James, Matteo Maggiori, Josefin Meyer, Vincent Reinhart, Lucie Stoppok, Jean Tirole and Jeromin Zettelmeyer for helpful comments. The views expressed herein are those of the authors and do not necessarily reflect the views of the National Bureau of Economic Research.

NBER working papers are circulated for discussion and comment purposes. They have not been peer-reviewed or been subject to the review by the NBER Board of Directors that accompanies official NBER publications.

(C) 2020 by Sebastian Horn, Carmen M. Reinhart, and Christoph Trebesch. All rights reserved. Short sections of text, not to exceed two paragraphs, may be quoted without explicit permission provided that full credit, including $(\odot$ notice, is given to the source. 
Coping with Disasters: Two Centuries of International Official Lending

Sebastian Horn, Carmen M. Reinhart, and Christoph Trebesch

NBER Working Paper No. 27343

June 2020

JEL No. E42,E5,F02,F3,F35,G01,G15,N1,N20

\begin{abstract}
$\underline{\text { ABSTRACT }}$
Official (government-to-government) lending is much larger than commonly known, often surpassing total private cross-border capital flows, especially during disasters such as wars, financial crises and natural catastrophes. We assemble the first comprehensive long-run dataset of official international lending, covering 230,000 loans, grants and guarantees extended by governments, central banks, and multilateral institutions in the period 1790-2015. Historically, wars have been the main catalyst of government-to-government transfers. The scale of official credits granted in and around WW1 and WW2 was particularly large, easily surpassing the scale of total international bailout lending after the 2008 crash. During peacetime, development finance and financial crises are the main drivers of official cross-border finance, with official flows often stepping in when private flows retrench. In line with the predictions of recent theoretical contributions, we find that official lending increases with the degree of economic integration. In crises and disasters, governments help those countries to which they have greater trade and banking exposure, hoping to reduce the collateral damage to their own economies. Since the 2000s, official finance has made a sharp comeback, largely due to the rise of China as an international creditor and the return of central bank cross-border lending in times of stress, this time in the form of swap lines.
\end{abstract}

\author{
Sebastian Horn \\ University of Munich \\ and Kiel Institute \\ sebastian.horn@econ.lmu.de \\ Carmen M. Reinhart \\ Kennedy School of Government \\ Harvard University \\ 79 JFK Street \\ Cambridge, MA 02138 \\ and CEPR \\ and also NBER \\ carmen_reinhart@harvard.edu
}

\author{
Christoph Trebesch \\ Kiel Institute for the World Economy \\ Research Area on International Finance \\ Kiellinie 66, \\ 24105 Kiel, \\ Germany \\ and CEPR and CESifo \\ christoph.trebesch@ifw-kiel.de
}




\section{Introduction}

The world of official (bilateral and multilateral) lending remains largely unexplored in the academic literature, despite the scale and relevance of this type of cross-border flows. Most studies focus on a single government or institution, such as US lending as part of the Marshall Plan or IMF bailouts during the Asian Crisis. Compared to the vast literature on private cross-border capital flows, research on official international financial flows has been limited by a lack of systematic data. Existing datasets on official debt and inter-governmental lending typically have a narrow focus (e.g. on development aid, concessionary lending) or they start only in the 1970s.

We collect lending data by 134 creditor countries and 50 international and regional financial organizations across 200 years, building on hundreds of sources, including international treaties, budget accounts, proprietary lending data by the World Bank, and archival material. In total, we identify more than 230,000 official loans, grants and guarantees from 1790 to 2015, with total commitments amounting to more than 15 trillion US Dollars (in constant 2015 terms). Using this data, we document the characteristics of official capital flows, link them to the occurrence of disasters (wars, financial crises and natural disasters), and study their determinants with a gravity model of bilateral lending since the $18^{\text {th }}$ century. Our main findings can be summarized as follows.

Official lending by governments, central banks, and multilateral institutions is larger than commonly known. Indeed, over the past two centuries, official creditors have played a major role in international finance. Since 1800 , official capital flows have repeatedly exceeded private cross-border flows. This is especially true during times of war, financial crises, or other disasters, when private flows decline and official actors become the chief international lenders.

The biggest surges in official lending occurred during major wars, in particular in WW1, WW2 and the Napoleonic wars. The amounts lent during these global conflicts were much larger than the loans made during global financial crises or major natural disasters. This adds perspective to modern debates on the international financial system, as there is a tendency to think of official finance as a complementary type of capital flows in the context of development aid and crisis bailouts. But this view reflects the fact that much of the world has enjoyed 70 years of peace. Global wars have been the most disruptive force in international finance.

In peacetime, the main driver of official international lending was and continues to be financial crises. We show that cross-border rescue lending during banking panics and currency crises has a long history, occurring repeatedly during the $19^{\text {th }}$ and early $20^{\text {th }}$ century, well before the creation of the IMF. The rescue loans extended in historical crises were substantial, e.g. in the crises of 1861 or 1890 , but they were granted ad hoc and to bridge short-term liquidity problems. In contrast, since 
WW2, financial crisis lending has become much more institutionalized and "serial" bailouts to highly indebted countries have become more common. This is partly the result of the rise of international and regional financial institutions, in particular the IMF and the World Bank. Lending by these multilateral creditors overtook total bilateral lending for the first time in the 1970s.

By comparing our novel data on official flows with previously assembled long-run data on private international capital flows by Reinhart, Reinhart and Trebesch (2019) we show that both series are negatively correlated. Official capital flows are highest when private capital flows dry out. During wartime, private investors usually face widespread capital controls, while governments lend at record pace internationally. Furthermore, the data show that official creditors were the "only game in town" during the Bretton Woods era in the 1950s and 1960s, while private cross-border capital flows were scarce and heavily curtailed. An expanded official role is also evident during the height of the Great Depression in the 1930s and during the 2008 global financial crisis and its aftermath on periphery Europe, when central bank and sovereign lending spiked, while private capital outflows reversed.

It is not widely appreciated that we witnessed a comeback of official lending in the past two decades. China's rise as an international creditor has been underestimated due to a lack of data and transparency. We document how China has become one of the most important official creditors worldwide, as almost all of its foreign lending is extended by the government and its state-owned banks (see also Horn, Reinhart and Trebesch 2019). China's official lending boom is part of a more general rise of new creditor powers, especially emerging markets such as Russia, India, Brazil or the Arab oil states, who have all become active official lenders in varying degrees. In addition, dozens of new official lending institutions were founded since WW2, including a range of regional development banks and regional financial arrangements in Asia, Africa and South America. The result has been a notable increase in "South-South" official sovereign lending. More generally, we find a much higher incidence of official loans in the current era. Today, most financial crises, natural catastrophes and wars are accompanied by official lending of some form. This was not the case historically.

Similarly, we are seeing a resurgence of official financing via central banks. During the financial crisis of 2008 the Federal Reserve Bank, the ECB and the Bank of Japan granted record amounts of "swap lines" via a network of standing credit lines that allow drawing overnight foreign currency loans (Bahaj and Reis 2019). These developments are reminiscent of the flourishing crossborder central bank lending during the gold standard era pre-WW1 and in the interwar years. The newly resurrected and intensely used Federal Reserve swap lines during the COVID-19 pandemic is yet another example. 
On the determinants of official flows, our results are consistent with the predictions of recent theoretical contributions. Tirole (2015), Farhi and Tirole (2018) and Gourinchas, Martin and Messer (2019) all predict the scope of bilateral official lending and bailouts to increase with economic and financial integration. When the negative spillovers from a crisis country are potentially high, e.g., due to close bank and trade linkages, countries have an incentive to grant rescue loans to the government facing the crisis. In so doing, creditor governments aim to reduce the collateral damage to their own economy.

Until now, it was difficult to test these priors systematically, due to data limitations. We connect the models and narratives in this literature to our new database. We estimate an augmented gravity model of bilateral official loans worldwide and across crises and disasters of the past two centuries (including more than 1700 dyads). We find that bilateral trade and bilateral bank exposure are indeed a key predictor of official lending flows in crisis times. Across all eras, countries were most willing to help others when private agents had significant economic or financial exposure in the recipient countries. The prevailing interpretation is that foreign official lending is a function of economic and political self-interest, rather than of altruism or more general "country solidarity". At the same time, official flows seem to be impeded by informational asymmetries, as the likelihood of rescue lending decreases significantly with higher geographic and cultural distance.

Our paper adds a significant missing piece to the literature on capital flows and the international monetary system. Research in this broad topic has almost exclusively focused on private capital flows (see, for example, Calvo, Leiderman and Reinhart 1993, Stone 1999, Obstfeld and Rogoff 2000, Obstfeld and Taylor 2004, Lane and Milesi-Ferretti 2007, Bruno and Shin 2013, Gourinchas and Jeanne 2013, Rey 2015, and Reinhart, Reinhart and Trebesch 2017). In contrast, there is only very little research on official capital flows (among the few exceptions is the pioneering work on official finance by Alfaro, Kalemli-Ozcan and Volosovych 2014, as well as some of our own work in Reinhart and Trebesch 2016 and Schlegl, Trebesch and Wright 2019). Given the size of official capital flows, both in the past and most recently, omitting official lending distorts the picture on the size and dynamics of international capital flows. The omission is most problematic during natural disasters, economic crises and war.

Our analysis also contributes to the literature on macroeconomic disasters (e.g. Barro 2006, Barro and Ursúa 2008, Gabaix 2012) and on the economics of international wars (e.g. Martin, Mayer and Thoenig 2005, Glick and Taylor 2010), by combining our dataset on official flows with data on inter-state conflicts, natural disasters and financial crises. Not unlike the literature on capital flows, economic research on disasters and wars has focused primarily on the implications for private capital markets and trade. We show that over the past 200 years, official lending repeatedly reached record 
heights during some macroeconomic disasters and all global wars, with large potential consequences for output, trade and asset markets alike (these effects remain largely unexplored).

More generally, our dataset allows us to address fundamental questions of international cooperation in a new way. Why do countries cooperate financially and what are the outcomes? Existing work on economic cooperation between sovereign states mainly focuses on cooperation in the realms of fiscal policy, exchange rate policy, or banking regulation (e.g. the seminal work of Kindleberger 1986, Eichengreen 1992, or James 1996). But, until now, there have been almost no systematic empirical analyses on the determinants of financial cooperation via sovereign-to-sovereign and central-bank-to-central-bank lending in the past and present, which is the focus here.

Another strand of related literature focuses on financial crises and sovereign debt problems. Countless papers have explored the pricing of privately held sovereign bonds and the determinants and effects of default by sovereign borrowers (see Reinhart and Rogoff 2009, Panizza et al. 2009, Aguiar and Amador 2014 or Meyer, Reinhart and Trebesch 2019 for overviews). In contrast, there has been very little work on lending by sovereigns. The history of official debt has long been overlooked in this research area, except for a body of work on IMF and World Bank lending, which, as we document, only became large in the 1970s and today accounts for a third of total official lending. We contribute to the literature on financial crises by conducting the first systematic long-run study on international official rescue lending during debt, currency and banking crises in both advanced and developing countries.

We thereby considerably expand the existing narratives and data collections on country bailouts, e.g. by Kindleberger (2006), Bordo and Schwartz (1998), Roubini and Setser (2004), Barkbu, Eichengreen and Mody (2012) or Corsetti, Erce and Uy (2017, 2018). Our data show that crisis lending has evolved from occasional, ad-hoc rescue loans by allied states to a global financial safety net with dozens of institutions. Besides covering the incidence, origin, and amounts of official lending, we also gathered information on the interest rates and repayment terms, as well as on the political conditions of official support. This data resource will allow further analyses on the determinants, design, and consequences of cross-border bailouts and will help to inform the theoretical literature on international crises (see above, as well as Summers 2000, Bordo et al. 2001 and Lorenzoni 2014, for overviews). ${ }^{2}$ By exploring political drivers of bilateral rescue lending we also add to existing work on the political economy of bailouts (Brown and Dinc 2005, Schneider and Tobin 2020).

\footnotetext{
${ }^{2}$ A small theoretical literature specifically studies sovereign bailouts across borders, e.g. Corsetti, Guimaraes and Roubini 2006, Morris and Shin 2006, Dellas and Niepelt 2016, Fink and Scholl 2016, Corsetti, Erce and Uy 2018, Roch and Uhlig 2018, as well as the references cited above Tirole (2015), Farhi and Tirole (2018) Gourinchas, Martin and Messer (2019).
} 
The remainder of the paper proceeds as follows: Section 2 provides information on who lends, tracking official creditors and institutions since 1790. This section also describes our coding and data sources. Section 3 presents our new database and provides a panoramic view on salient features of official sovereign lending across two centuries: We identify the main creditors and the (de jure) purposes of official lending over time and document the time profile of official transfers. We also examine the correlation of official flows with private international capital flows. In Section 5, we turn to official lending in times of crises and disasters. To do so we compile a new database on the occurrence of different disasters that tracks financial crises, military conflict and severe natural disasters. In Section 5 we explore the determinants of official lending by estimating an augmented gravity model of bilateral rescue loans. Section 6 concludes.

\section{Measuring official sovereign lending: methodology and sources}

The main challenge to the study of official international lending is the lack of systematic and encompassing data, with most available data not going back any further than the mid-1970s. We therefore embark on a large-scale data collection effort with the objective of constructing the first long-run database on official flows over two centuries. This section offers a sketch of the main elements of our database, while Appendix III provides a much more detailed overview on our sources and coding approach.

We define official international lending (conventional definition) as all loans, grants and guarantees extended by a sovereign, supra-sovereign or sub-sovereign creditor entity to a foreign sovereign or non-sovereign debtor. By this definition, official creditors include both bilateral and multilateral institutions, as well as sub-sovereign creditors such as a state-owned export and development banks. Given the relative scarcity of discussion on official lending in history, the next subsection provides a brief background on the universe of official creditor institutions over the past 200 years. This sets the stage for the subsequent description of our data sources.

\subsection{Official creditors and institutions since 1790}

Figure 1 provides a stylized representation of the evolution of the official creditor universe, distinguishing between bilateral and multilateral institutions. Throughout the $19^{\text {th }}$ century and up until the 1920s, official international loans were exclusively extended by bilateral creditors, namely by the treasuries, foreign and colonial offices and war ministries of nations, as well as by national central banks. These institutions were not specialized on providing foreign loans, but took up the task when special circumstances required them to do so, very often under considerable political controversy. 
Figure 1. The universe of official sovereign creditor institutions $1790-2015$

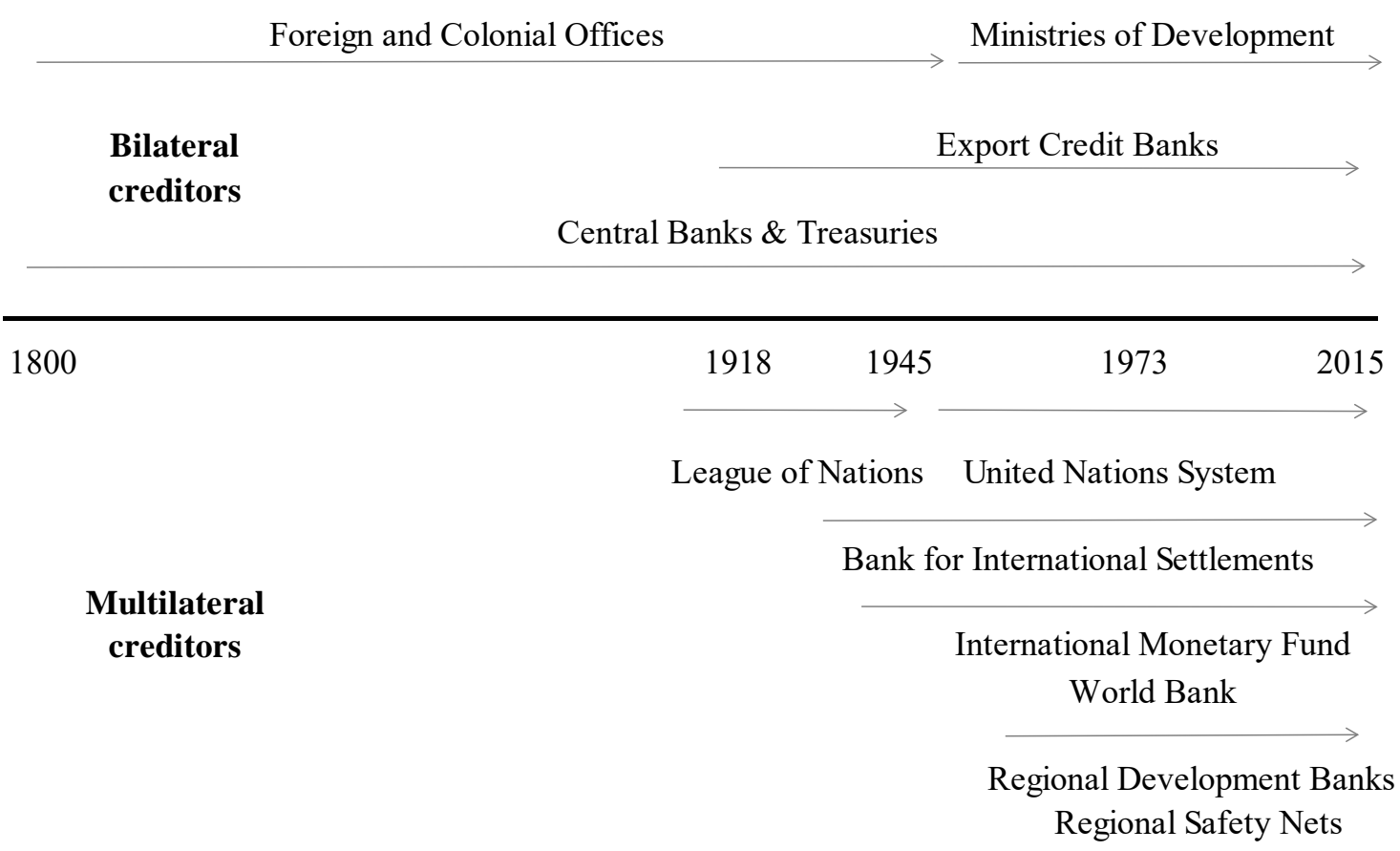

Sources: Official international lending database and Cogan et al. (2016).

The practice of official sovereign lending across borders changed profoundly with the onset of World War I. European sovereigns established a new type of official creditor institution: stateowned export banks that guaranteed private trade credits and directly extended buyer credits to foreign sovereigns, in particular to the Soviet Union that had lost access to private capital markets (Margold, 1934). In addition, the League of Nations, founded in 1920, started to cooperate with national treasuries to mobilize rescue loans for crisis countries in need, especially in Central and Eastern Europe where governments tried to stabilize their currencies after the war (Flores Zendejas and Decorzant, 2016). In doing so, they were supported by increasingly active central banks, which extended record amounts of rescue loans to other central banks facing capital and gold outflows in an effort to support the interwar gold standard. This era of central bank cooperation peaked during the crisis of 1931 and quickly receded afterwards. Guided by the newly founded Bank of International Settlements (BIS), central banks mobilized significant emergency credits to Central Europe and Britain to stem the turmoil caused by the retrenchment of private flows, with limited success (Accominotti and Eichengreen, 2015).

The crisis of 1931 and its aftermath mark a turning point in the development of official international lending. The crisis highlighted the volatile nature of private capital flows and led leading policy-makers and academics to acknowledge the importance of counter-cyclical official lending 
(Nurkse, 1944). During the course of the 1930s, the United States joined European states in extending official loans to states with balance-of-payments problems, in particular through the US Export-Import Bank and the US Treasury's Exchange Stabilization Fund, which was established in 1934.

The lessons learned during these operations turned out to have great effect on the design of the post-World War II Bretton Woods System (Bordo and Schwartz, 2001). In 1944, the IMF was founded with the aim of providing short-term official funds to countries with temporary balance-ofpayments problems, alongside with the World Bank that was intended to provide long-term development and reconstruction funds. However, official lending during the post-war decades continued to be dominated by bilateral creditors. The US, in particular, engaged in large scale lending, e.g. via the Marshall Plan and EXIM Bank funds. Also the Soviet Union became an active official lender. Furthermore, outside the convertible dollar and sterling areas, sovereigns financed their current account deficits with the reciprocal extension of clearing credits.

Starting from the late 1950 s, the practice of official lending began to gradually shift from bilateral to multilateral creditor institutions, driven by a remarkable increase in the number and variety of multilateral lending institutions. Regional development banks first emerged in the late 1950s with the establishment of the European Development Fund and the Inter-American Development Bank and have spread to all regions of the globe since. In parallel, new Regional Financial Arrangements (RFAs) were set up, typically focused on providing emergency funds during balance-of-payments crises of member states. Early examples include the European Monetary Agreement founded in 1958 and the Central American Monetary Stabilization Fund of 1970. More recently, the European Stability Mechanism (ESM) founded in 2012, is just one manifestations of this long-run trend towards regional rescue facilities (Scheubel and Stracca 2016). Beyond regional and multilateral arrangements, central bank swap lines have become an additional main source of official emergency finance. Starting with the defense of the Bretton Woods system in the 1960s, a network of bilateral swap lines has been in place that connects the major central banks of the world. More recently, these networks have been expanded in size and scope. They now include the central banks of main emerging markets and, driven by China's central bank, also a growing number of developing countries.

Taken together, these institutional developments have transformed the practice of official sovereign lending from occasional instances of ad hoc cooperation between two states into a multilayered, global financial safety net composed of a broad range of specialized institutions. 


\subsection{Main sources and scope of the database}

Our new database compiles loans, grants and guarantees from the majority of these official creditors and several hundred primary and secondary sources that are described in detail in Appendix III. The resulting database spans official lending from 1790 to 2015 and covers more than 230,000 loans, grants and guarantees extended by national agencies of up to 134 bilateral creditor countries and by 50 different international organizations (see Appendix III for a full list). Whenever available we collected data on the creditor and the borrower, both commitment and disbursement amounts, the purpose of the loan as well as the interest rates and repayment terms. In other cases, our data is more aggregate. At the minimum, however, our database contains creditor and borrower country as well as commitment amounts at the annual level allowing us to identify source and direction of official lending and thus the bilateral patterns of international official flows. We now sketch the main sources used in constructing the database.

International treaty series: Our main source for official lending during the $19^{\text {th }}$ century and leading up to World War II are international treaty collections. In doing so, we make use of the fact that the conduct of foreign policy became increasingly formalized in the late $18^{\text {th }}$ century, so that international loans between two states were now codified in inter-governmental treaties (Keene 2012). Our sources show that, over the course of the 150 years from 1790 to World War II, sovereigns negotiated thousands of bilateral treaties, in which they regulated their political and commercial interactions. To identify bilateral lending, we systematically search the available treaty collections and related databases for bilateral financial agreements that arrange the extension of loans and grants or that extend guarantees on privately issued international loans or bonds.

National budget accounts and parliamentary records: For the main bilateral creditor countries prior to World War II, we supplement the information obtained from international treaties with national budget accounts and parliamentary records. In the absence of specialized creditor entities, international official loans often required parliamentary approval and we can use these sources as important consistency check. Furthermore, they allow us to capture within-empire (country) transactions, e.g. lending to colonies, for which no inter-governmental treaties exist. More specifically, we comb through the national budgets and parliamentary records of the UK, France, Germany and the US starting in the early $19^{\text {th }}$ century.

Reports and datasets from international organizations: Starting from the inter-war period, publications and data by international organizations become an additional, highly valuable source. We make extensive use of regular research reports on international capital flows by the League of Nations, the BIS, the IBRD, the UN, the OECD and the IADB. We also use a wide range of creditor specific 
sources, such as recently declassified CIA reports on foreign lending by Sino-Soviet Bloc countries and the annual reports of a large number of bilateral and multilateral creditor institutions. Moreover, and most importantly, we supplement this hand-coded data with a comprehensive data-extract on bilateral lending from the World Bank's Debtor Reporting System (DRS), which was shared with us on a confidential basis. Specifically, the DRS records all bilateral lending transactions of all member states reporting to the World Bank, starting in the 1960s. For aid flows and grants, our main sources are the OECD's Creditor Reporting System and the database provided by AidData at William \& Mary (Tierney et al., 2011).

Archival research (especially central bank archives): For a subgroup of official creditors no published reports of sufficient detail are available. This is particularly the case for central banks and the BIS. In these cases, we go through the archives of these institutions and collect data from original reports and documents. Appendix III provides details on this (ongoing) data collection process.

Secondary sources: Finally, we draw on the existing literature on international capital flows and international political relations. These sources, again listed in Appendix III, allow us to complement and cross-check our own data.

Figure 2. Illustration of historical sources - international financial agreements and budget reports

Panel A

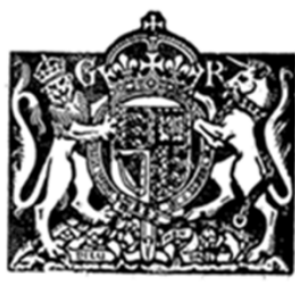

Treaty Series No. 7 (1929)

AGREEMENT BETWEEN HIS MAJESTY'S GOVERNMENT IN THE UNITED KINGDOM AND THE GOVERNMENT OF EGYPT relative to the Ottoman Guaranteed Loan of 1855 and other Financial Questions

CAIRO, MARCH 17,1929
Panel B

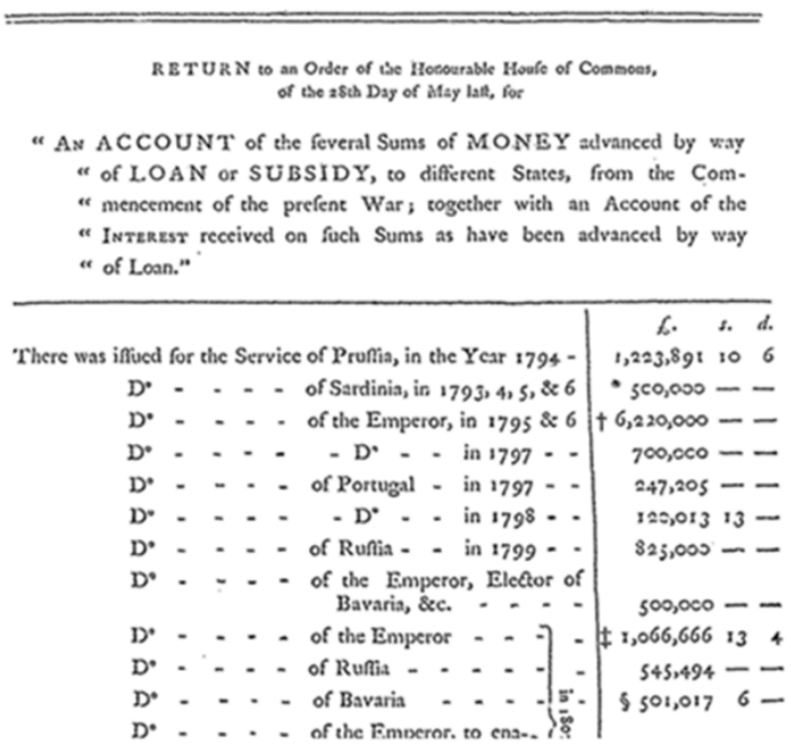

Note: This figure shows examples for the most common historical sources used to construct our database in the $19^{\text {th }}$ century. We show an extract from an international financial treaty (left panel) as well as from a national budget report (right panel). For a detailed description of the data and the sources see Appendix III. 


\section{Official sovereign lending 1790 - 2015: A panoramic view}

This section introduces our new database and gives a descriptive overview on the occurrence and magnitude of official sovereign lending from 1790 to 2015 . We discuss the main creditors, recipients and purposes of official lending over time.

Figure 3. Bilateral and multilateral official lending $1790-2015$

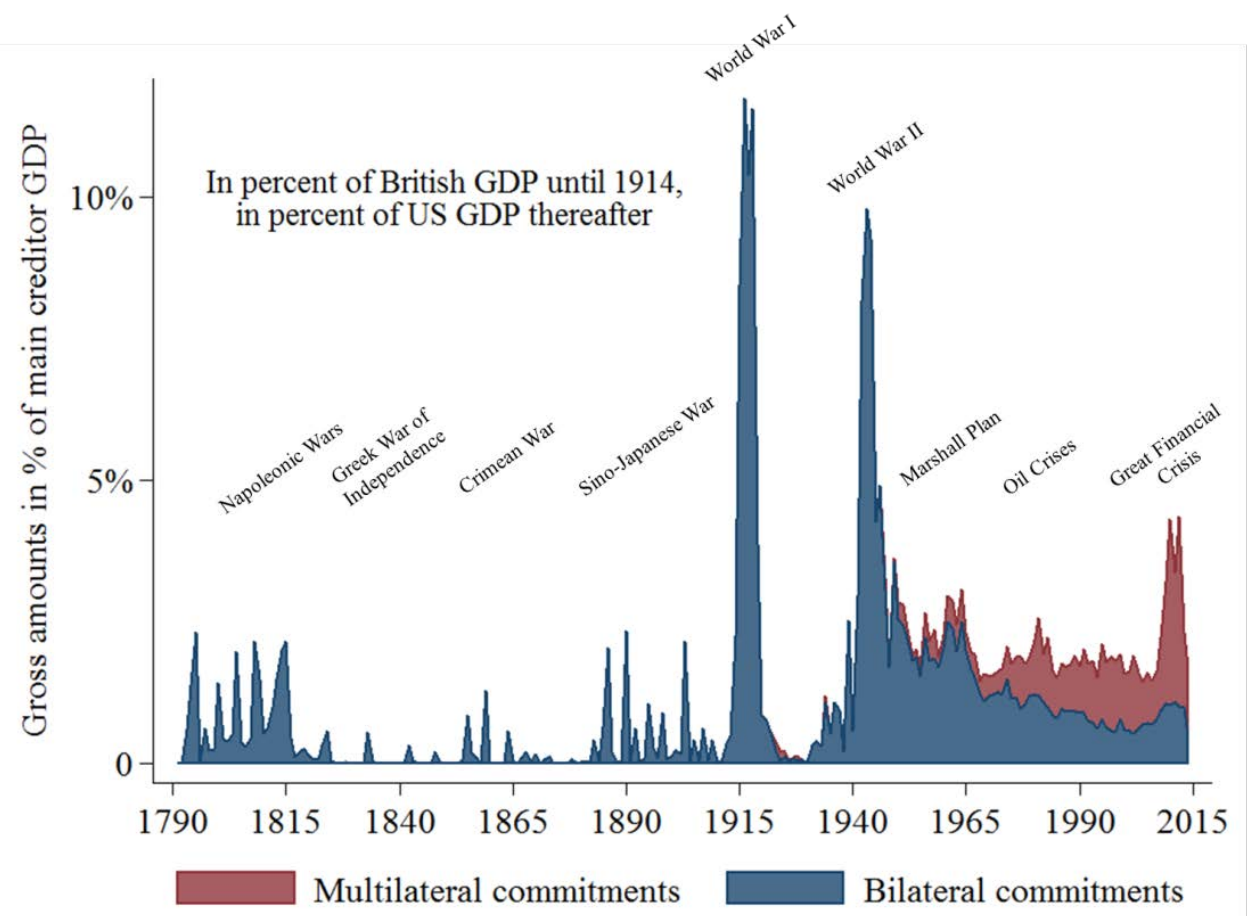

Note: The data includes commitments through grants, loans and guarantees, but excludes official portfolio investments and central bank lending (see below. The data is from the international official lending database that we construct (see Appendix III for details).

Figure 3 summarizes the ebbs and flows of inter-governmental lending, by showing annual gross commitments by bilateral and multilateral creditors since the French Revolution. All amounts are scaled by the GDP of the most important official creditor country. Specifically, we use UK GDP until the onset of the First World War (1914) and US GDP thereafter. While there are various alternative scaling options, the use of US and UK GDP offers comprehensive coverage. ${ }^{3}$ Official lending was dominated by bilateral creditors until the Second World War. With the foundation of the IMF and the World Bank Group, lending gradually shifted from bilateral to multilateral sources.

\footnotetext{
${ }^{3}$ The main conclusions of this section are not altered when using alternative series for scaling, e.g. world GDP.
} 
During the 1970s, multilateral lending first overtook bilateral lending and has remained dominant since then.

To further distinguish by type of creditor, Figure 4 shows the share of total official lending since 1900 for (i) bilateral creditors, (ii) the IMF and the World Bank, and (iii) other multilateral creditors, in particular regional development banks and regional financial arrangements. It can be seen that the third category of "other" multilateral creditors is now more important than ever.

Figure 4. Relative importance of multilateral and bilateral creditors over time

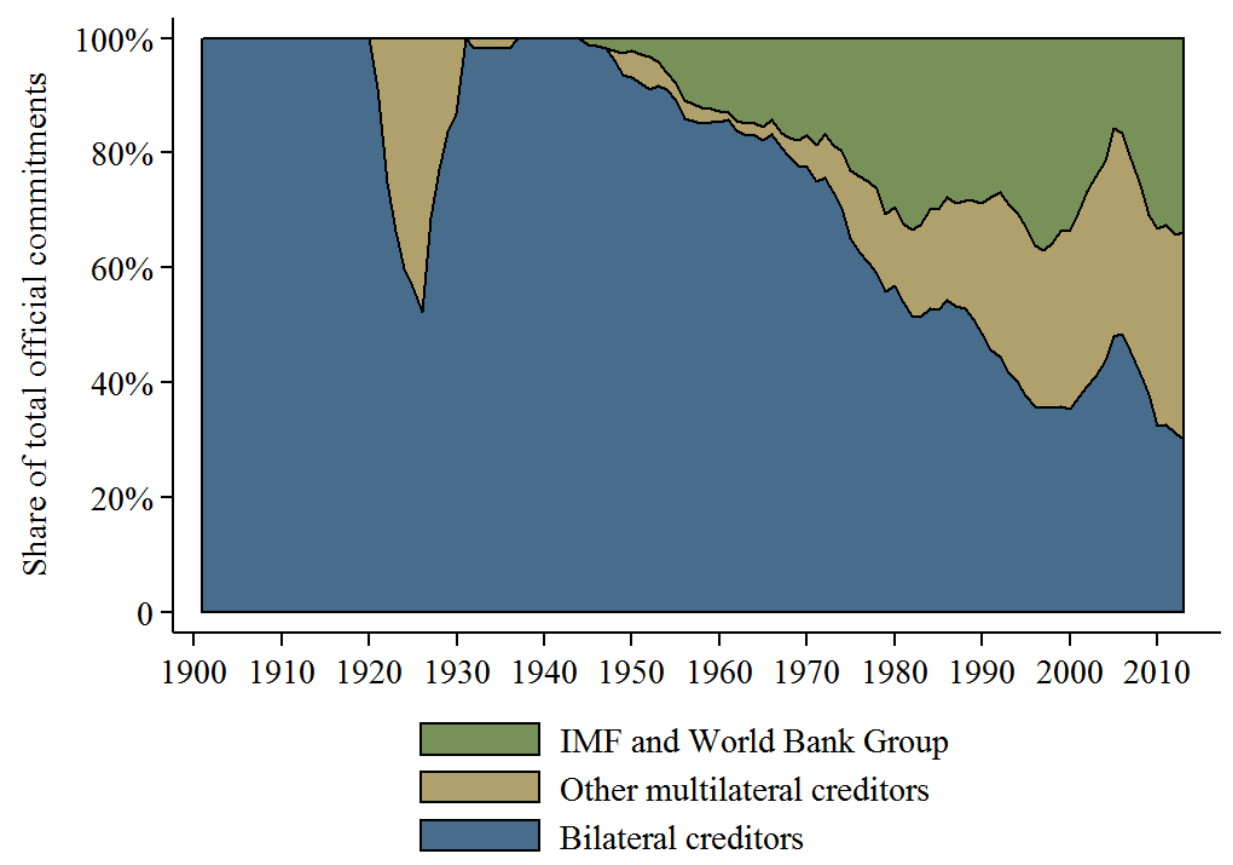

Note: Other multilateral creditors (yellow area) include different regional development banks and regional financial arrangements as well as loans issued under the auspices of the League of Nations (see appendix III.6 for a full list). Bilateral creditors are represented by the blue area. All three series are smoothed by applying a five-year moving average. Source: international official lending database (see Appendix III).

Within the group of bilateral creditors, the relative importance of individual countries varies markedly over time, reflecting long-run shifts in economic and political power. Up until the First World War, bilateral lending was dominated by the Great European Powers, in particular Great Britain and France. Over the course of the two World Wars and throughout the Cold War, the United States emerged as the world's primary official creditor. In comparison, official lending by the Soviet-Sino bloc was small, although it increased until the 1980s. During the oil crises of the 1970s, oil exporting nations suddenly became a major source of official international lending. Since then, in particular after the end of the Cold War, the international landscape of bilateral lending has become more heterogeneous. In line with their growing share of world output and trade, emerging market countries 
have established themselves as leading bilateral creditors. This development is driven by China, which has recently surpassed the US, the World Bank and the IMF as the world's most important official creditor (see Horn, Reinhart and Trebesch 2019).

Figure 5. Recipients of official sovereign lending 1790 - 2015

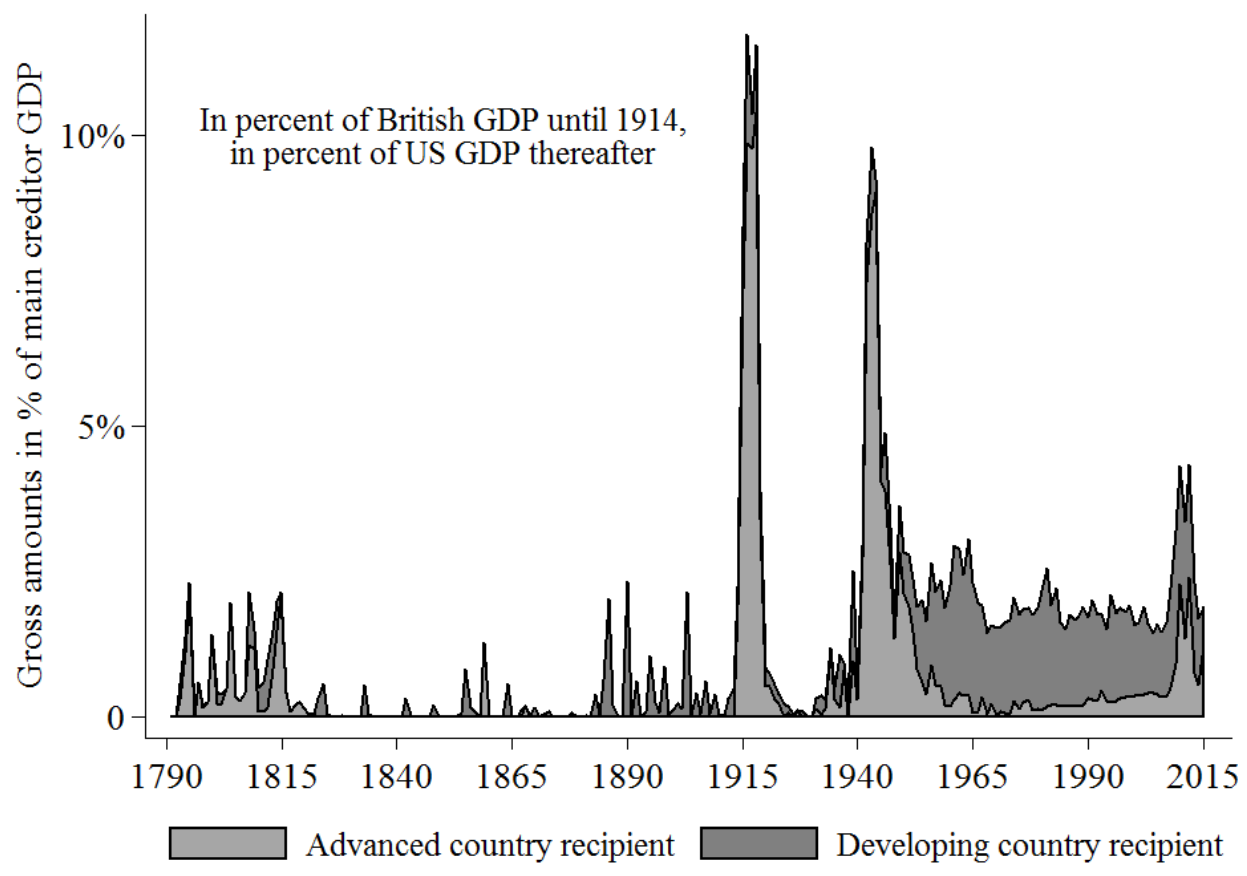

Note: The data includes commitments through grants, loans and guarantees, but excludes official portfolio investments and central bank swap credit. Data is from the international official lending database (Appendix III).

Not just the creditors, but also the recipients of official flows have changed markedly over the course of the past 200 years. Today, official sovereign lending is often associated with rescue lending and aid to developing countries. Indeed, Figure 5 shows that the bulk of official lending between 1960 and the 2000s went to developing countries. Before that, however, over a span of more than 150 years, advanced countries have been the main recipients of official loans, especially during times of global war. Also more recently, after the 2008 financial crisis and the 2010-12 Eurozone crisis, advanced countries received large-scale official lending, via regional and multilateral financial arrangements, as well as via central bank swap lines (see below).

To provide a first overview on the motives of government-to-government and multilateral official lending over the past 200 years we distinguish between four categories of lending purposes military assistance, economic development, humanitarian relief, and financial crisis rescues. The category of military assistance covers loans and grants extended for the pursuit of war, defense or procurement of military equipment. The category of economic development includes loans and grants 
extended for the financing of projects in developing countries ranging from infrastructure investments to state-building activities. The category of humanitarian relief relates to financial assistance in response to natural disasters, e.g. grants to purchase basic necessities such as food. The fourth category, financial rescue loans, covers loans, grants and guarantees during currency, debt and banking crises, including balance-of-payment crises, as well as general budget support.

Figure 6. The purpose of official sovereign lending 1790 - 2015

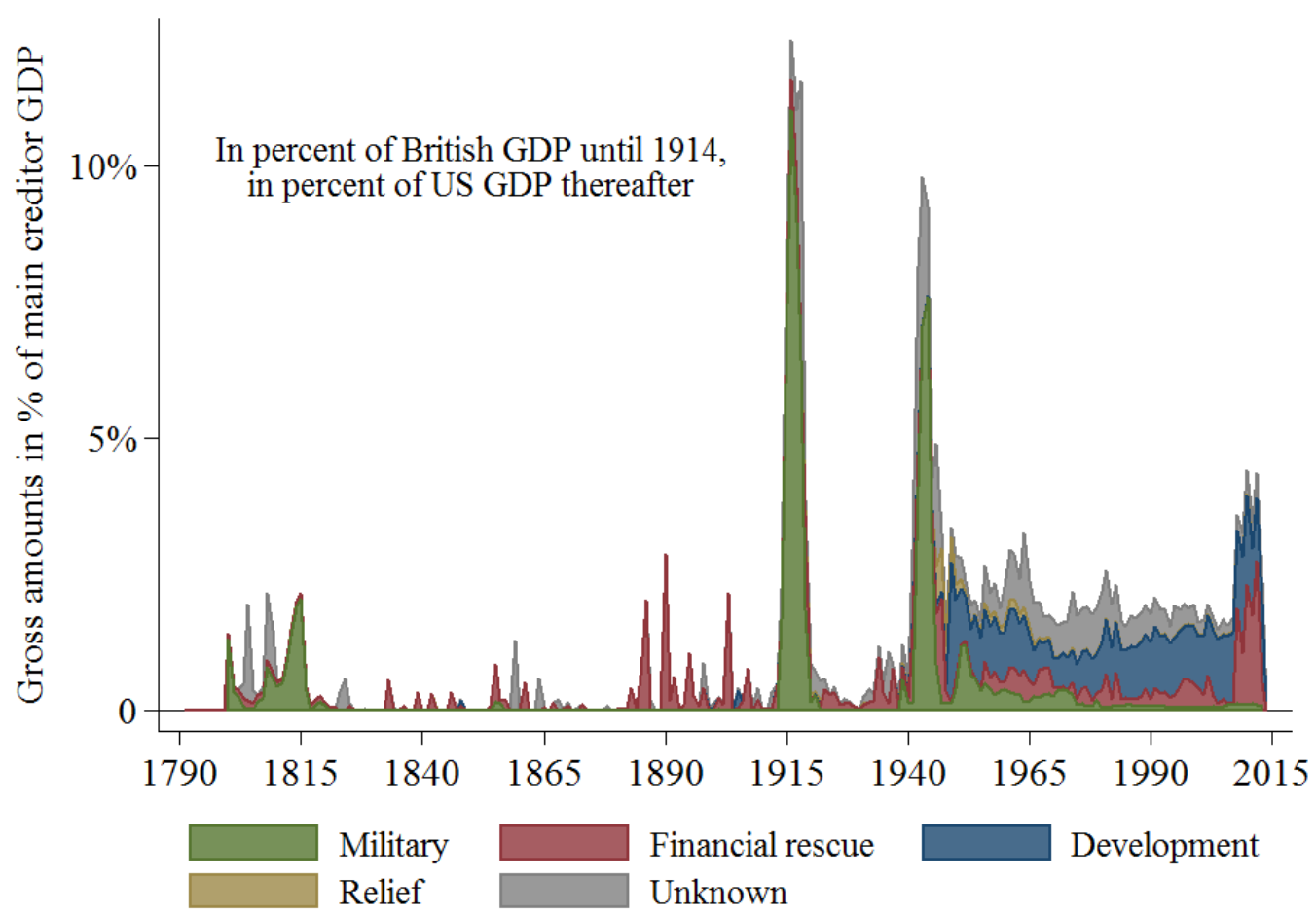

Note: The data includes commitments through grants, loans and guarantees, but excludes official portfolio investments and central bank swap credit. Data is from the international official lending database (Appendix III).

Whenever possible, we rely on the original sources to distinguish between these purposes, although we are aware that the distinction is not always clear-cut and involves a number of judgement calls. One problem is that the officially declared purpose of a loan does not necessarily need to align with its de facto purpose. As an example, foreign currency loans for development projects are often provided during a financial crisis, in order to address a severe balance-of-payment problem. Moreover, we sometimes lack official information on the lending purpose so that we need to infer the purpose from events at the time. Despite these caveats and challenges, Figure 6 is helpful as a first descriptive 
overview and to motivate our more systematic analysis of official lending during disasters in sections 4 and 5 .

Figures 3 and 6 illustrate that, during the 19th century and up to World War I official sovereign lending was heavily concentrated in times of major wars. Notable lending surges occurred during the French Revolutionary Wars, the Napoleonic Wars and the First Crimean War. In each case the Great European Powers provided substantial financial support to their allies by means of loans, guarantees and grants. Similarly, during the Latin American Wars of Independence the newly founded republics cooperated financially through the extension of loans and grants in an effort to win against Spain. With respect to financial crises, there were repeated instances of official rescue lending during banking panics, through reciprocal credits between central banks (see below and Eichengreen 1992, Bordo and Schwartz 1998). In contrast, there are only few cases of official lending during sovereign debt crises, e.g. the official guarantees on private bonds issued by Greece in 1832 and 1898. Sovereign defaults were more commonly left to market forces or solved through enforced adjustments in the form of super-sanctions (Mitchener and Weidenmier 2010, Tuncer 2015). Moreover, prior to World War I, we found few instances of official lending in response to natural disasters or famines and also official lending for development purposes was very limited throughout the $19^{\text {th }}$ century, with the exception of transactions within empires, where grants and loans were occasionally used to build infrastructure and to contain the negative effects of military conflict, e.g. in Transvaal after the Second Boer War.

During the first half of the $20^{\text {th }}$ century, the two World Wars stand out, leading to historically unprecedented levels of international assistance. Interestingly, however, the aftermaths of the two wars look very different. After World War I, official flows quickly dried up, with only modest lending for relief and reconstruction. In contrast, after 1945, official lending remained strong over the course of the entire Bretton Woods era. US bilateral loans, in particular, played a crucial role in the closing of the Dollar Gap and the reconstruction of Europe (mostly connected with the Marshall Plan). This period - from the break-down of the inter-war gold exchange standard in 1931 to the late 1960s can be considered the heyday of official finance. With wide-spread capital controls on private flows and financial repression, official loans constituted the only feasible means of international capital transfers.

With the collapse of the Bretton Woods System and the steady rise in private capital mobility, the purpose of official lending changed again. There are increasing financial flows to finance domestic development and infrastructure projects in developing countries. These countries often lack access to international private capital markets, so that official lending in the form of aid is often the only source of foreign savings. Figure 6 shows that the scale of official flows for development finance 
has remained remarkably stable over the past decades. In contrast, official flows to advanced and emerging economies are more volatile, driven mainly by economic and political crises. Indeed, it is the incidence of major financial crises that explain most of the recent spikes in bilateral and multilateral commitments, including the official rescue packages extended during the Oil Crises, the emerging markets crises of the 1980s and 1990s and most recently during the Great Financial and the subsequent Euro Debt Crisis.

Over the past two decades, and especially after 2008 we are witnessing a comeback of official finance, thus reversing a decade-long trend of gradual decline. Besides the large-scale international bailouts during the financial crisis, it is the rise of China and of other emerging donor countries such as India or resource-rich Arab countries that has contributed to a resurgence of bilateral lending. Today, bilateral lending, in particular from China, constitutes a prime source of external financing for dozens of low-income and emerging countries (Horn, Reinhart and Trebesch 2019).

Another important reason for the comeback in official finance is the re-emergence of crossborder central bank lending. Figure 7 adds credits and swap lines extended between central banks to the total volume of official loan commitments (thus combining Figure 3 and Figure 8 below). The graph reveals that international central bank credits have been quantitatively important both today and in history, with credits exceeding $2 \%$ of UK or US GDP in different spells of the past 200 years.

During the $19^{\text {th }}$ century, there were repeated episodes with sizeable central bank lending, including the Panic of 1861, the Baring Crisis in 1890 and the Panic of 1907 . In the $20^{\text {th }}$ century, international central bank lending intensified during the interwar years. In the 1920s, for example, consortia of central banks agreed to extend reciprocal credits so as to help each other return to gold (Meyer 1970). In 1931, central bank lending reached a historic peak, with total credits exceeding 3\% of US GDP. Yet, these rescue credits, mainly extended to Austria, Hungary, Germany and Britain, did not suffice to prevent the inter-war gold standard from collapsing (Accominotti and Eichengreen, 2015). Beyond these rescue operations, the US Federal Reserve granted a series of short-term credits to Latin American countries facing balance-of-payments difficulties during the 1930s.

In the decades following World War II, central bank lending across borders played a crucial role in the defense of the Bretton Woods System of fixed exchange rates during the 1960s and involved sizeable drawings on the Federal Reserve's swap line network, with support flowing to the US, the UK and France (see also Bordo, Humpage and Schwartz, 2015). 
Figure 7. Adding central bank lending: short-term credits and swaps across borders

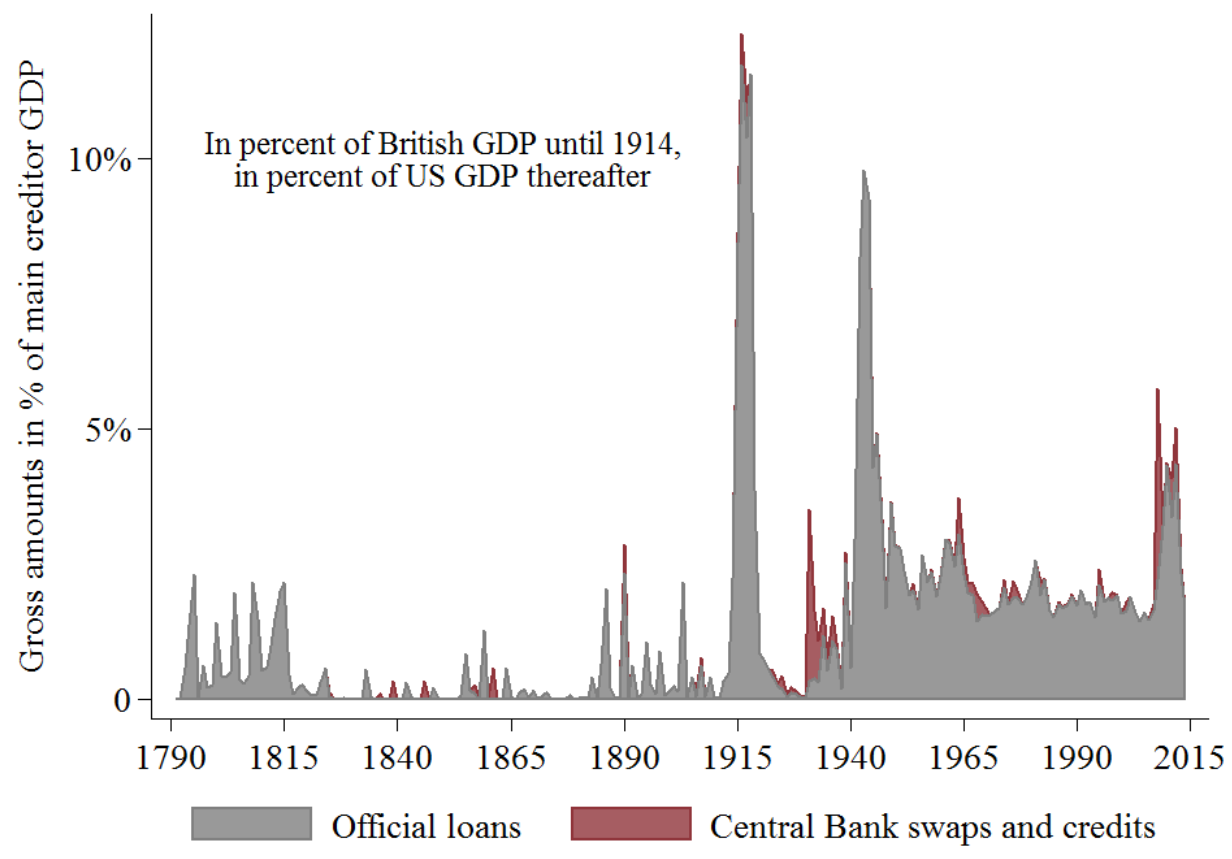

Note: This graph adds data on central bank lending (see Figure 8) to the data on bilateral and multilateral official loans (from Figure 3). The central bank lending data includes short-term credits to foreign central banks, as well as bilateral swap line drawings (after WW2). See Figure 8 for details.

Figure 8. Central bank lending across borders, 1815-2015

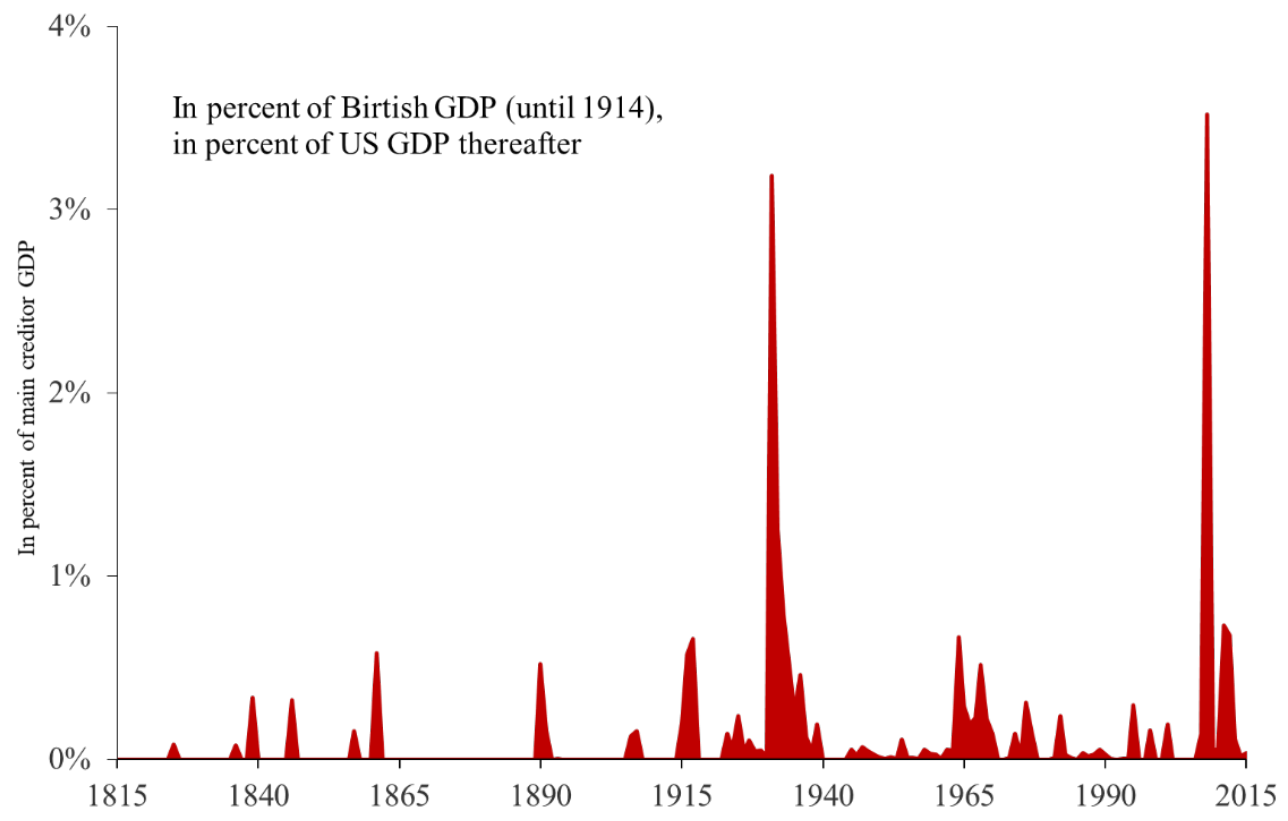

Note: The graph shows a time series on our ongoing data collection on cross-border central bank lending since 1815. The data includes central bank short-term credits to foreign central banks as well as bilateral swap line drawings (after WW2), shown in percent of UK GDP until 1914 and in percent of US GDP thereafter. 
Figure 8 above illustrates the re-emergence of large-scale international central bank lending during the 2008 crash, at a scale not seen since the interwar years. This time lending took the form of large-scale liquidity swap line drawings, rather than short-term credits like in the 1920s and 30s (Bahaj and Reis 2019). Figure 9 adds to this by focusing on the US Federal Reserve swap line network, with total drawings shown in USD since 2007. At the peak of the financial crisis in end-2008, total crossborder swap line drawings by foreign central banks exceeded 500 billion USD, a whopping amount that corresponds to more than $3 \%$ of USD GDP of 2008. This is not far from the latest spike in US swap line drawings since the start of the COVID-19 crisis. As of May 2020, 400 billion USD have been drawn, corresponding to more than 2\% of US GDP of 2019.

Figure 9. US Federal Reserve liquidity swaps extended to foreign central banks (in billion USD)

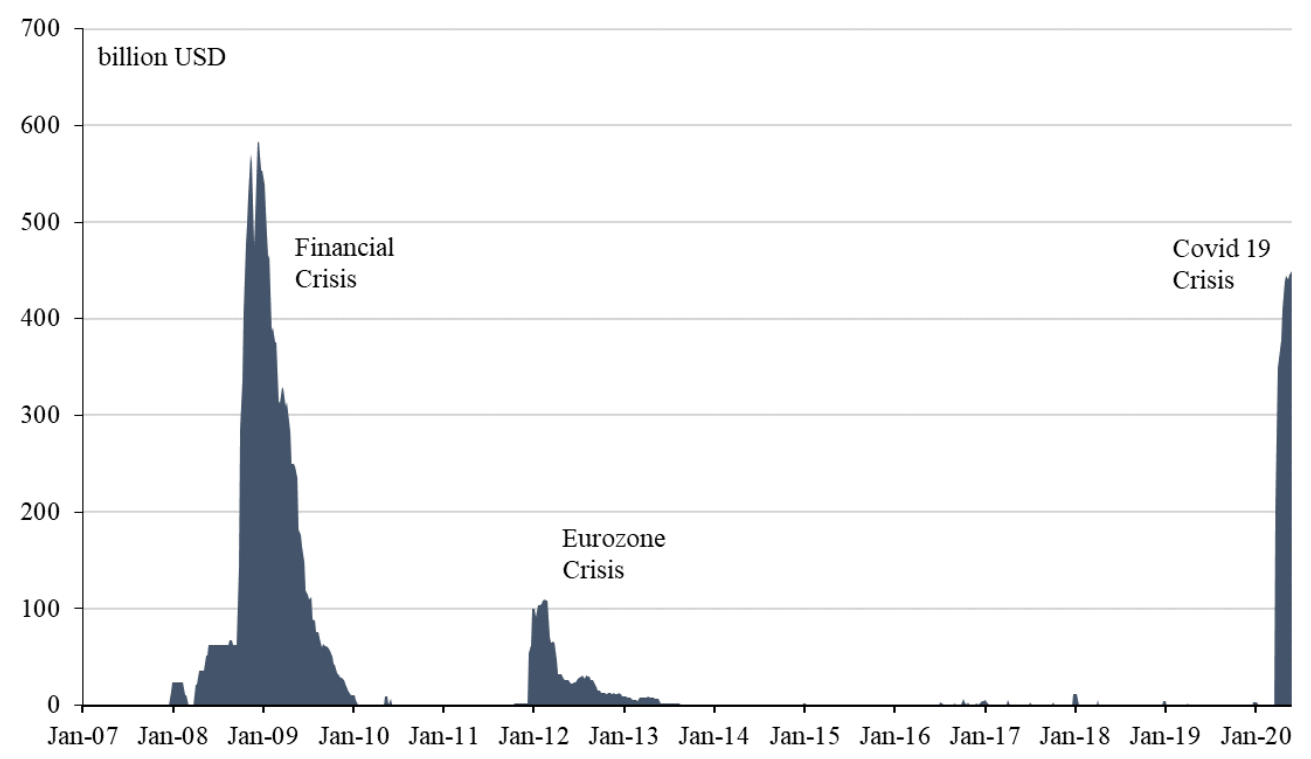

Note: The data includes total drawings on the US liquidity swap network by foreign central banks on a weekly basis. Source: Federal Reserve Bank of St. Louis (FRED).

To conclude our panoramic overview, we now compare the ebbs and flows of official international lending with those of private capital flows. Figure 10 combines our series of official lending commitments since 1790 with the long-run series of private cross-border capital flows from Reinhart, Reinhart and Trebesch $(2016,2019)$, which starts in 1815 and builds on their newly constructed "Global Capital Flow Database". More specifically, the series on private capital flows splices newly collected data on primary bond issuances in international markets (gross flows, until WW1) with data on net capital flows to 63 capital importing countries, building on newly collected country data on current accounts and gold and foreign exchange reserves since the interwar years (global net capital flows, after WW1). 
Figure 10 sheds new light on the history of the International Monetary System. A first take away is that the magnitudes of official and private cross-border capital flows are comparable in size, with international flows exceeding private flows in several historical spells. This finding is confirmed when comparing gross private and official flows, i.e. by merging our newly assembled official lending data with data on total sovereign bond issuance in international markets from Meyer, Reinhart and Trebesch (2019) or End, Mariko and Miryugin (2019). In particular during periods of stress, official international lending to sovereigns tends to be higher than total private sovereign lending by international banks and bondholders.

Figure 10. Official sovereign lending and private capital flows 1790 - 2015

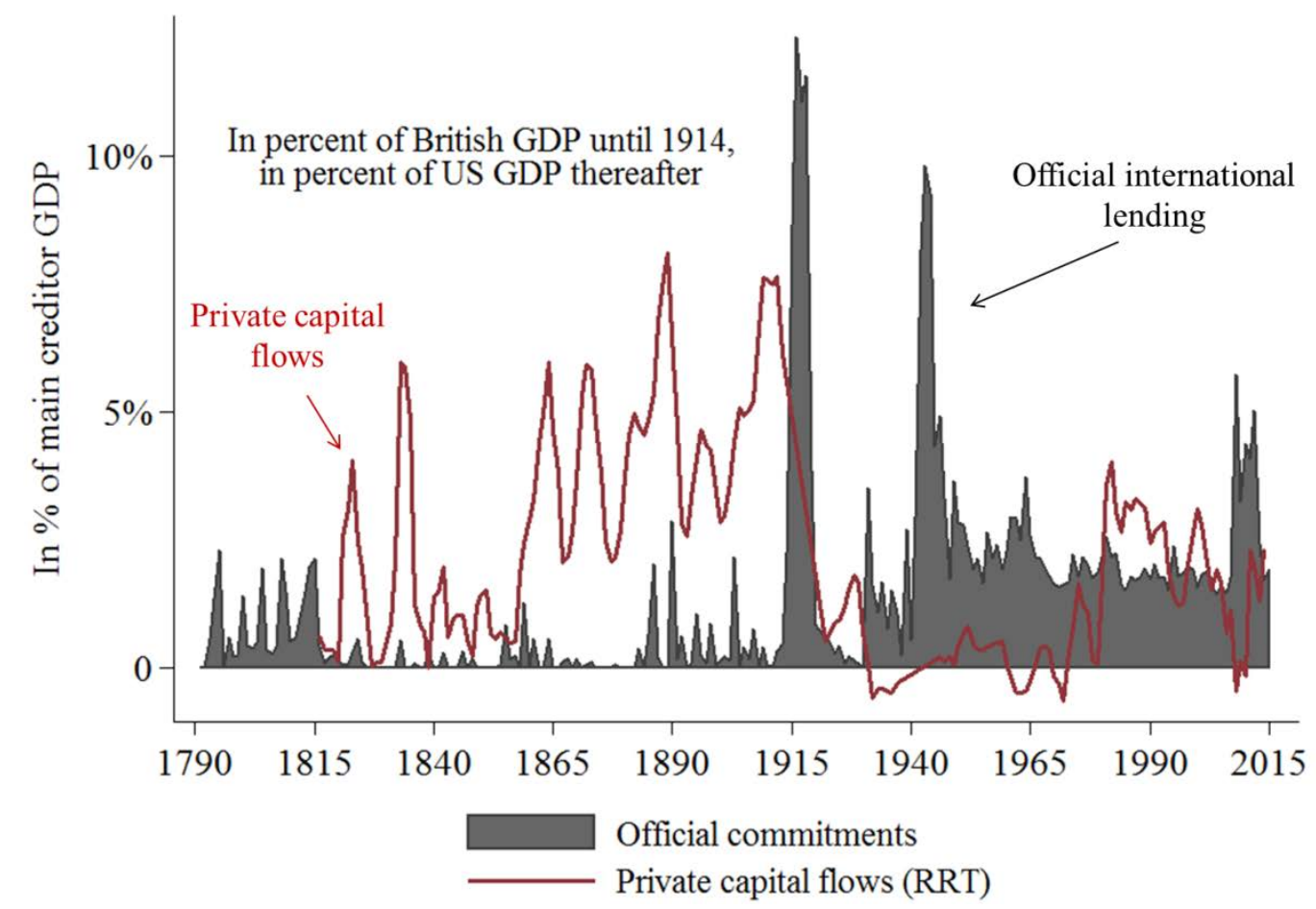

Note: The grey shaded era shows official international lending, including bilateral and multilateral commitments through grants, loans and guarantees, as well as central bank lending and swap line drawings. The red bold line shows the spliced series on private, cross-border capital flows from Reinhart, Reinhart and Trebesch $(2016,2019)$. Both series are scaled by main creditor GDP.

The second main take away from Figure 10 is that official and private flows are negatively correlated. When private capital flows retrench, official international flows often step in, with major multilateral and bilateral lending surges during WW1 and WW2 as well as in major financial crises, most visibly during the Great Depression (after 1930) and after the 2008 crash, but also in more idiosyncratic, regional crises such as during the 1960s or the European exchange rate crisis of the early 1990s. 


\section{Official lending in wars, financial crises and natural disasters}

In this section, we match our data on official sovereign lending with data on the occurrence of disasters, more specifically of wars, financial crises and severe natural catastrophes such as earthquakes. This allows us to study the international response to crises across different eras of the international financial system. We begin by compiling a comprehensive database on disaster and crisis events in the past 200 years and then match this with our novel dataset on official lending.

\subsection{Identifying disasters and defining crisis events}

To identify financial crises, military conflicts and severe natural disasters, we make use of a variety of sources. This section provides an overview, while details are described in Appendix I. Our approach focuses on actual disaster dates and events, in contrast to a related macroeconomic literature that defines "macroeconomic disasters" as drops in consumption or GDP beyond a specific threshold (see Barro and Ursúa 2010). The advantage of using event data is that it allows for much broader geographic and time coverage, given that long-run consumption and GDP data is only available for advanced countries and a few select emerging market countries. Furthermore, event-based data allows for a more granular analysis, e.g. by differentiating between different types of shocks and disasters.

To identify financial crises, we rely on the data of Reinhart and Rogoff (2009), and the data update by Meyer et al. (2019). We consider banking, currency and external sovereign debt crises and follow the crisis definitions brought forward by Reinhart and Rogoff (see Appendix I).

Our definition of wars follows the Correlates of War (CoW) project, namely a sustained combat, involving organized armed forces and resulting in a minimum of 1000 battle-related fatalities over the course of a 12 months period (Sarkees and Wayman 2010). The CoW data collection distinguishes inter-state and intra-state conflict, both of which are included as disaster events here. International or inter-state conflicts are defined as wars between two or more territorial states that are members of the international state system. Intra-state (or civil) wars are defined by sustained military combat within a state and with active participation of the national government. In the CoW database, war begins with the onset of sustained military combat, irrespective of a formal declaration of war.

Measuring natural disasters and the resulting damages and casualties over 200 years is challenging. To build a long-run dataset we draw on a large number of sources. First and most importantly, we draw on the EM-DAT International Disaster Database, which contains information on several thousand natural disasters around the globe since 1900, including geophysical (earthquakes and volcano eruptions), meteorological (extreme temperatures and storms), hydrological (floods and landslides), climatological (droughts, famines and wildfires) and biological disasters such as 
epidemics. To expand the data coverage to the 19th century, we supplement this source with information from the National Center for Environmental Information, which lists events of earthquakes, volcano eruptions, floods, tsunamis, and storms going back until 1800. In addition, we make use of multiple historical and country studies on famines and epidemics during the $19^{\text {th }}$ century, as listed in Appendix I.

Table 1. Number of disaster events in different eras: 1800-2015

\begin{tabular}{|c|c|c|c|c|}
\hline & $\begin{array}{c}\text { Long 19th Century } \\
1800-1913\end{array}$ & $\begin{array}{c}\text { Inter-War Period } \\
1914 \text { - } 1945\end{array}$ & $\begin{array}{c}\text { Bretton Woods } \\
1946-1973\end{array}$ & $\begin{array}{l}\text { Modern Era } \\
1973-2015\end{array}$ \\
\hline Financial crises & 254 & 235 & 164 & 416 \\
\hline $\begin{array}{l}\text { Severe natural } \\
\text { disasters }\end{array}$ & 44 & 28 & 20 & 16 \\
\hline Military conflict & 157 & 70 & 104 & 154 \\
\hline $\begin{array}{l}\text { Total number of } \\
\text { disaster events }\end{array}$ & 455 & 333 & 288 & 586 \\
\hline
\end{tabular}

Sources: See text and Appendix I for details.

The resulting dataset identifies several thousand natural disasters since 1800. Given our focus on disasters that warrant the provision of international financial assistance, we focus only on the most severe events. To do so, we match our list of natural disasters with population data from Mitchell (2013) and include only those natural disasters that result in casualties of at least 0.1 percent of the population. This yields 108 severe natural disaster events over the course of the past 200 years. While the timing of the disaster event is straight-forward with respect to earthquakes, floods or hurricanes, it can be difficult to accurately measure the duration of famines and epidemics. For these episodes, we consider the initial two years of the outbreak.

Table 1 summarizes the number of disasters and their frequency across different eras. Figure 11 also plots the incidence of disasters but takes a different perspective. It shows the share of independent countries that experience war, enter financial crises or suffer from severe natural disasters in any given year since 1800 based on our sample. Figure 11 reveals that the time-variation in the number of disasters is primarily driven by the waves of financial crises and military conflict that are spatially correlated. In contrast, the occurrence of severe natural disaster events is less cyclical and fairly constant over time. 
Figure 11. Incidence of wars, crises and natural disasters $1800-2010$

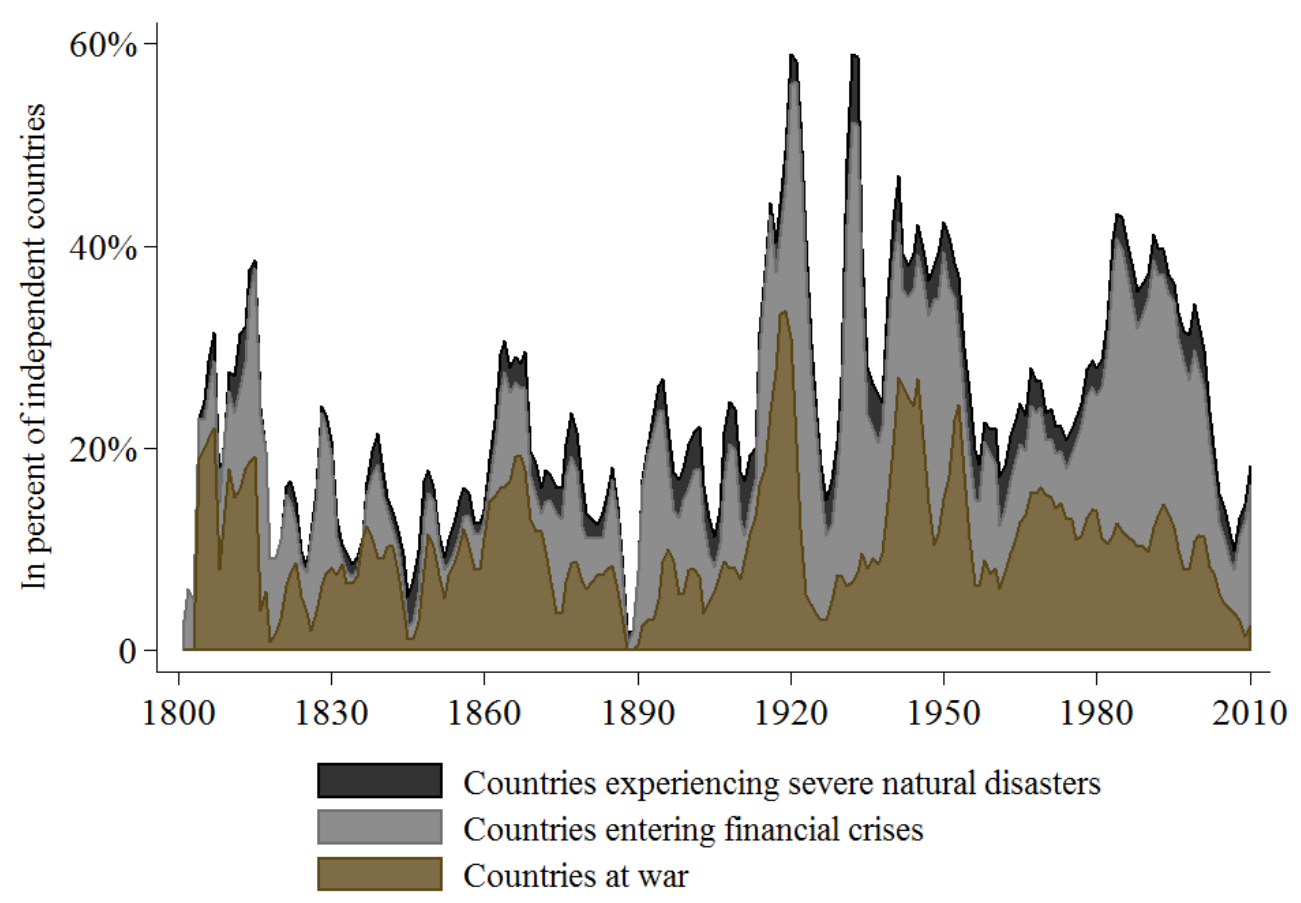

Note: Share of countries experiencing disasters. See text and Appendix I for details.

\subsection{The international response to disasters - descriptives and case narratives}

In this section we merge our new data on official lending with the above described data on disaster events in order to analyze the international response to disasters over the past 200 years. We begin by presenting case narratives for each type of disaster and then turn to a more systematic assessment of the incidence of rescue lending across time.

The following tables show selected cases of international financial rescues in severe natural disasters (Table 2), during military conflicts (Table 3) and during financial crises (Table 4). For each of the listed episodes, the tables show the most important recipients, the main official creditors and the magnitude of assistance provided. The cases illustrate that international official lending played an important role in a wide variety of disaster events and across all eras. 
Table 2. Natural disasters and their official international response: selected cases, 1800-2015

\begin{tabular}{|c|c|c|c|c|}
\hline Natural disaster & Year & $\begin{array}{c}\text { Main } \\
\text { recipient(s) }\end{array}$ & $\begin{array}{c}\text { Main } \\
\text { donor(s) }\end{array}$ & $\begin{array}{l}\text { Official assistance } \\
\text { (in real } 2015 \text { USD } \\
\text { and as \% of recipient } \\
\text { GDP or imports) }\end{array}$ \\
\hline Famine & $1811-1813$ & Portugal, Russia & United Kingdom & $\$ 27 \mathrm{mn}$ \\
\hline Caracas Earthquake & 1812 & Venezuela & USA & $\$ 1 \mathrm{mn}$ \\
\hline Hurricane & 1836 & Dominica & United Kingdom & $\$ 1.2 \mathrm{mn}$ \\
\hline $\begin{array}{l}\text { Volcano eruption, } \\
\text { earthquakes }\end{array}$ & 1843 & Antigua, Montserrat & United Kingdom & $\$ 21 \mathrm{mn}$ \\
\hline $\begin{array}{c}\text { Eruption of Mount } \\
\text { Pelée }\end{array}$ & 1902 & Martinique & $\begin{array}{l}\text { United Kingdom, } \\
\text { France }\end{array}$ & $\$ 14 \mathrm{mn}$ \\
\hline Famine & 1913 & Albania & United Kingdom & $\$ 0.2 \mathrm{mn}$ \\
\hline $\begin{array}{c}\text { Famines } \\
\text { (following WWI) }\end{array}$ & $1919-1923$ & Europe & $\begin{array}{c}\text { USA, UK, } \\
\text { France, Norway }\end{array}$ & $\$ 12$ bn \\
\hline Jericho Earthquake & 1927 & Transjordan & United Kingdom & $\$ 1.4 \mathrm{mn}$ \\
\hline Flood & 1949 & Guatemala & US, Cuba & $\begin{array}{c}\$ 46 \mathrm{mn} \\
7 \% \text { of imports }\end{array}$ \\
\hline $\begin{array}{l}\text { Valdivia } \\
\text { Earthquake }\end{array}$ & 1960 & Chile & IMF, IBRD, US & $\begin{array}{c}\$ 6 \text { bn } \\
12 \% \text { of GDP } \\
230 \% \text { of imports }\end{array}$ \\
\hline Famine & $1983-1985$ & Ethiopia & $\begin{array}{l}\text { UN, IDA, Soviet } \\
\text { Union }\end{array}$ & $\begin{array}{c}\$ 4 \text { bn } \\
27 \% \text { of GDP } \\
260 \% \text { of imports }\end{array}$ \\
\hline Cyclone & 1991 & Bangladesh & $\begin{array}{l}\text { UN, IDA, G-7 } \\
\text { countries }\end{array}$ & $\begin{array}{c}\$ 4.3 \mathrm{bn} \\
8 \% \text { of GDP } \\
68 \% \text { of imports }\end{array}$ \\
\hline Tsunami & 2004 & Sri Lanka & $\begin{array}{l}\text { UN, IDA, Japan, } \\
\text { China }\end{array}$ & $\begin{array}{c}\$ 3 \text { bn } \\
14 \% \text { of GDP } \\
45 \% \text { of imports }\end{array}$ \\
\hline Earthquake & 2010 & Haiti & $\begin{array}{l}\text { UN, IADB, US, } \\
\text { France }\end{array}$ & $\begin{array}{c}\$ 6 \text { bn } \\
90 \% \text { of GDP } \\
200 \% \text { of imports }\end{array}$ \\
\hline
\end{tabular}

Note: This table shows the scale of official rescue lending in selected severe natural disasters of the past 200 years. The size of official assistance is given in real 2015 US Dollars. Whenever data availability permits, we show the magnitude of assistance in percent of recipient GDP and imports (using pre-disaster values). 
Table 3. Military conflicts and their international response: selected cases, 1800 - 2015

\begin{tabular}{|c|c|c|c|c|}
\hline $\begin{array}{c}\text { Military } \\
\text { conflict }\end{array}$ & Year & $\begin{array}{l}\text { Main } \\
\text { recipient(s) }\end{array}$ & $\begin{array}{c}\text { Main } \\
\text { donor(s) }\end{array}$ & $\begin{array}{c}\text { Official assistance } \\
\text { (in real } 2015 \text { USD } \\
\text { and as \% of recipient } \\
\text { GDP or imports) }\end{array}$ \\
\hline $\begin{array}{c}\text { French } \\
\text { Revolutionary } \\
\text { Wars }\end{array}$ & $1792-1802$ & Austria, Prussia & United Kingdom & $\$ 2$ bn \\
\hline Napoleonic Wars & $1803-1815$ & $\begin{array}{c}\text { Austria, Prussia, } \\
\text { Russia, Portugal, } \\
\text { Sweden }\end{array}$ & United Kingdom & $\$ 5$ bn \\
\hline Crimean War & $1853-1856$ & $\begin{array}{c}\text { Sardinia, } \\
\text { Ottoman Empire }\end{array}$ & $\begin{array}{l}\text { United Kingdom, } \\
\text { France }\end{array}$ & $\$ 950 \mathrm{mn}$ \\
\hline $\begin{array}{c}1^{\text {st }} \text { Sino-Japanese } \\
\text { War }\end{array}$ & 1895 & China & France, Russia & $\begin{array}{c}\$ 2.1 \mathrm{bn} \\
0.5 \% \text { of GDP } \\
66 \% \text { of imports }\end{array}$ \\
\hline World War I & $1914-1918$ & UK, France, Russia & US, UK, France & $\$ 475$ bn \\
\hline $\begin{array}{c}2^{\text {nd }} \text { Sino-Japanese } \\
\text { War }\end{array}$ & $1935-1938$ & China & $\begin{array}{l}\text { USA, Soviet } \\
\text { Union }\end{array}$ & $\begin{array}{c}\$ 2.7 \mathrm{bn} \\
22 \% \text { of GDP } \\
135 \% \text { of imports }\end{array}$ \\
\hline $\begin{array}{c}\text { Spanish Civil } \\
\text { War }\end{array}$ & 1936 & Spain & $\begin{array}{l}\text { Germany, Italy, } \\
\text { Soviet Union }\end{array}$ & $\begin{array}{c}\$ 12.5 \mathrm{bn} \\
11 \% \text { of GDP } \\
256 \% \text { of imports }\end{array}$ \\
\hline World War II & $1939-1945$ & $\begin{array}{l}\text { UK, Germany, } \\
\text { Soviet Union }\end{array}$ & USA & $\$ 800$ bn \\
\hline Vietnam War & $1956-1975$ & South Vietnam & USA & $\$ 150$ bn \\
\hline Yom-Kippur War & 1973 & Israel & USA & $\begin{array}{c}\$ 2.6 \mathrm{bn} \\
4 \% \text { of GDP } \\
20 \% \text { of imports }\end{array}$ \\
\hline
\end{tabular}

Note: This table shows the scale of official rescue lending in selected severe wars and military conflicts of the past 200 years. The size of official assistance is given in real 2015 US Dollars. Whenever data availability permits, we further show the magnitude of assistance in percent of pre-disaster recipient country GDP and imports. 
Table 4. Financial crises and their international response: selected cases, 1800 - 2015

\begin{tabular}{|c|c|c|c|c|}
\hline $\begin{array}{l}\text { Financial } \\
\text { crisis }\end{array}$ & Year & $\underset{\text { recipient(s) }}{\text { Main }}$ & $\begin{array}{c}\text { Main } \\
\text { donor(s) }\end{array}$ & $\begin{array}{l}\text { Official assistance } \\
\text { (in real } 2015 \text { USD and as \% of } \\
\text { recipient GDP or imports) }\end{array}$ \\
\hline Panic of 1925 & 1825 & United Kingdom & France & $\begin{array}{c}\$ 45 \mathrm{mn} \\
0.7 \% \text { of GDP } \\
1 \% \text { of imports } \\
\$ 290 \mathrm{mn}\end{array}$ \\
\hline Banking Crisis & 1846 & France & United Kingdom & $\begin{array}{l}0.6 \% \text { of GDP } \\
6 \% \text { of imports }\end{array}$ \\
\hline $\begin{array}{l}\text { World Economic } \\
\text { Crisis }\end{array}$ & 1857 & Hamburg & Austria & $\begin{array}{c}\$ 150 \mathrm{mn} \\
2 \% \text { of imports }\end{array}$ \\
\hline Baring Crisis & 1890 & United Kingdom & France, Russia & $\begin{array}{c}\$ 575 \mathrm{mn} \\
0.2 \% \text { of GDP } \\
1 \% \text { of imports }\end{array}$ \\
\hline Panic of 1907 & 1907 & United Kingdom & France & $\begin{array}{c}\$ 390 \mathrm{mn} \\
0.1 \% \text { of GDP } \\
0.5 \% \text { of imports }\end{array}$ \\
\hline $\begin{array}{c}\text { Post WWI } \\
\text { Stabilization }\end{array}$ & $1919-1923$ & Austria & $\begin{array}{c}\text { UK, France, } \\
\text { League of Nations }\end{array}$ & $\begin{array}{c}\$ 5.7 \text { bn } \\
22 \% \text { of GDP } \\
135 \% \text { of imports }\end{array}$ \\
\hline $\begin{array}{c}\text { Currency } \\
\text { stabilization }\end{array}$ & 1927 & Italy & $\begin{array}{l}\text { Consortium of } 16 \\
\text { Central Banks }\end{array}$ & $\begin{array}{c}\$ 1 \mathrm{bn} \\
0.5 \% \text { of GDP } \\
7.2 \% \text { of imports }\end{array}$ \\
\hline Crisis of 1931 & 1931 & Germany & $\begin{array}{c}\text { France, UK, USA, } \\
\text { BIS }\end{array}$ & $\begin{array}{c}\$ 8 \mathrm{bn} \\
2 \% \text { of GDP } \\
20 \% \text { of imports }\end{array}$ \\
\hline Crisis of 1931 & 1931 & United Kingdom & France, USA & $\begin{array}{c}\$ 19 \mathrm{bn} \\
4 \% \text { of GDP } \\
24 \% \text { of imports }\end{array}$ \\
\hline $\begin{array}{l}\text { Currency \& debt } \\
\text { crisis }\end{array}$ & $1934-1937$ & Brazil & USA & $\begin{array}{c}\$ 1.5 \mathrm{bn} \\
2 \% \text { of GDP } \\
50 \% \text { of imports }\end{array}$ \\
\hline $\begin{array}{c}\text { Dollar Gap \& } \\
\text { Reconstruction of } \\
\text { Europe }\end{array}$ & $1946-1952$ & Western Europe & USA & $\$ 280$ bn \\
\hline $\begin{array}{l}\text { Currency \& debt } \\
\text { crisis }\end{array}$ & 1956 & Hungary & $\begin{array}{l}\text { Soviet Union, } \\
\text { China }\end{array}$ & $\begin{array}{c}\$ 2.7 \mathrm{bn} \\
4 \% \text { of GDP } \\
94 \% \text { of imports }\end{array}$ \\
\hline $\begin{array}{l}\text { Defense of } \\
\text { Sterling }\end{array}$ & 1964 & United Kingdom & IMF, BIS, G-10 & $\begin{array}{c}\$ 30 \mathrm{bn} \\
5 \% \text { of GDP } \\
30 \% \text { of imports }\end{array}$ \\
\hline
\end{tabular}




\begin{tabular}{|c|c|c|c|c|}
\hline First Oil Crisis & $1974-1976$ & Italy & $\begin{array}{l}\text { IMF, EEC, } \\
\text { Germany }\end{array}$ & $\begin{array}{c}\$ 23 \mathrm{bn} \\
3 \% \text { of GDP } \\
25 \% \text { of imports }\end{array}$ \\
\hline $\begin{array}{l}\text { Developing } \\
\text { Country Debt } \\
\text { Crisis }\end{array}$ & $1982-1983$ & Brazil & $\begin{array}{l}\text { IMF, IBRD, IADB, } \\
\text { Germany, USA }\end{array}$ & $\begin{array}{c}\$ 33 \mathrm{bn} \\
5 \% \text { of GDP } \\
50 \% \text { of imports }\end{array}$ \\
\hline Tequila Crisis & $1994-1995$ & Mexico & IMF, USA & $\begin{array}{c}\$ 76 \mathrm{bn} \\
10 \% \text { of GDP } \\
68 \% \text { of imports }\end{array}$ \\
\hline Asian Crisis & 1997 & Thailand & IMF, Korea, Japan & $\begin{array}{c}\$ 18 \text { bn } \\
7 \% \text { of GDP } \\
16 \% \text { of imports }\end{array}$ \\
\hline $\begin{array}{l}\text { Great Financial } \\
\text { Crisis }\end{array}$ & $2008-2010$ & Ukraine & IMF, EU, USA & $\begin{array}{c}\$ 50 \text { bn } \\
31 \% \text { of GDP } \\
65 \% \text { of imports }\end{array}$ \\
\hline $\begin{array}{l}\text { Eurozone Debt } \\
\text { Crisis }\end{array}$ & $2010-2015$ & Greece & Eurozone, IMF & $\begin{array}{c}\$ 475 \text { bn } \\
144 \% \text { of GDP } \\
550 \% \text { of imports }\end{array}$ \\
\hline
\end{tabular}

Note: This table shows selected official rescue packages during financial crises of the past 200 years. The size of official assistance is given in real 2015 US Dollars. Whenever data availability permits, we further show the magnitude of assistance in percent of pre-disaster recipient country GDP and imports.

One insight from the case narratives is that international official assistance following disasters was rare historically, in fact, so rare that we lowered the bar and also show some cases in which total population losses were lower than $0.1 \%$ of the population (these cases are not included in the regression analysis below). Among the few notable historical cases are US aid flows after the Caracas earthquake of 1812 and international aid to the Caribbean in response to the 1843 volcano eruption on Guadeloupe. Moreover, the committed amounts in the context of natural disasters were typically low, not just by modern standards but also in comparison to the sizeable official lending during wars of the same era. Over time, the amounts grow and in the recent decades there are a few cases in which natural disasters triggered large-scale official aid flows, e.g. Ethiopia's famines in the mid-1980s, the tsunami in the Indian Ocean in 2004 or the earthquake in Haiti of 2010.

Generally, the cases illustrate that the amounts of official lending have increased over time, both in absolute terms and as percent of recipient GDP or imports. This is particularly true for international bailouts in financial crises. Notable examples include the Sterling Crisis of 1964 in which the UK received USD 30 billion (5\% of GDP), the Tequila Crisis of 1994/95 in which Mexico received USD 76 billion (10\% of GDP), as well as the recent bailouts of Ukraine after 2008 (50 billion 
USD, or $31 \%$ of GDP) and Greece after 2010 (Greece received a whopping 475 billion USD or 375 billion Euro in bailouts, corresponding to $144 \%$ of Greek GDP, see Reinhart and Trebesch 2015b).

We continue our analysis with a more systematic analysis on the incidence of international rescue lending during disasters, focusing on the overlap between the two. Figure 12 shows the share of independent countries that experienced disasters (black line) as well as the subset of these countries that received international official assistance at the same time (grey shaded areas). The figure considers financial crisis, natural catastrophes and military conflict as defined above.

Figure 12. Incidence of official rescue lending in disasters (all types, 1800-2015)

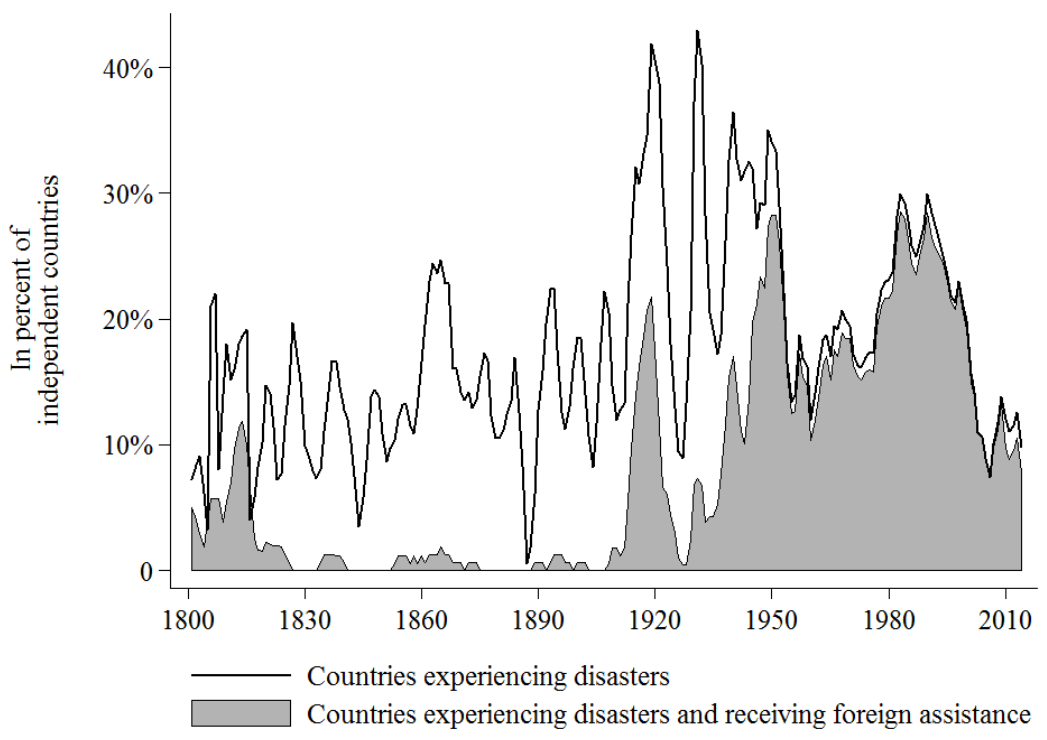

Note: This figure shows the share of independent countries that experience a disaster (black solid line), as well as the subset of these countries that also receive international official assistance (grey shaded area).

The main take away from Figure 12 is that official international lending in disasters has become much more prevalent and systematic over the course of the past 200 years. Since the interwar period, an ever-larger share of crisis countries received foreign financial support. Since World War II the share of recipients has almost reached a hundred percent, with only very few countries entering crises without receiving any foreign financial help. Institutionally, this trend reflects the emergence of a multi-layered financial safety net for sovereigns that provides ready-to-use access to a large array of standing financing and risk-sharing options. Figure 13 goes a step further and explores the incidence of rescue lending by type of disaster. It shows that the trend towards more systematic international rescues is visible for all disaster types. 
Figure 13. Incidence of rescue lending by type of disaster (1800-2015)
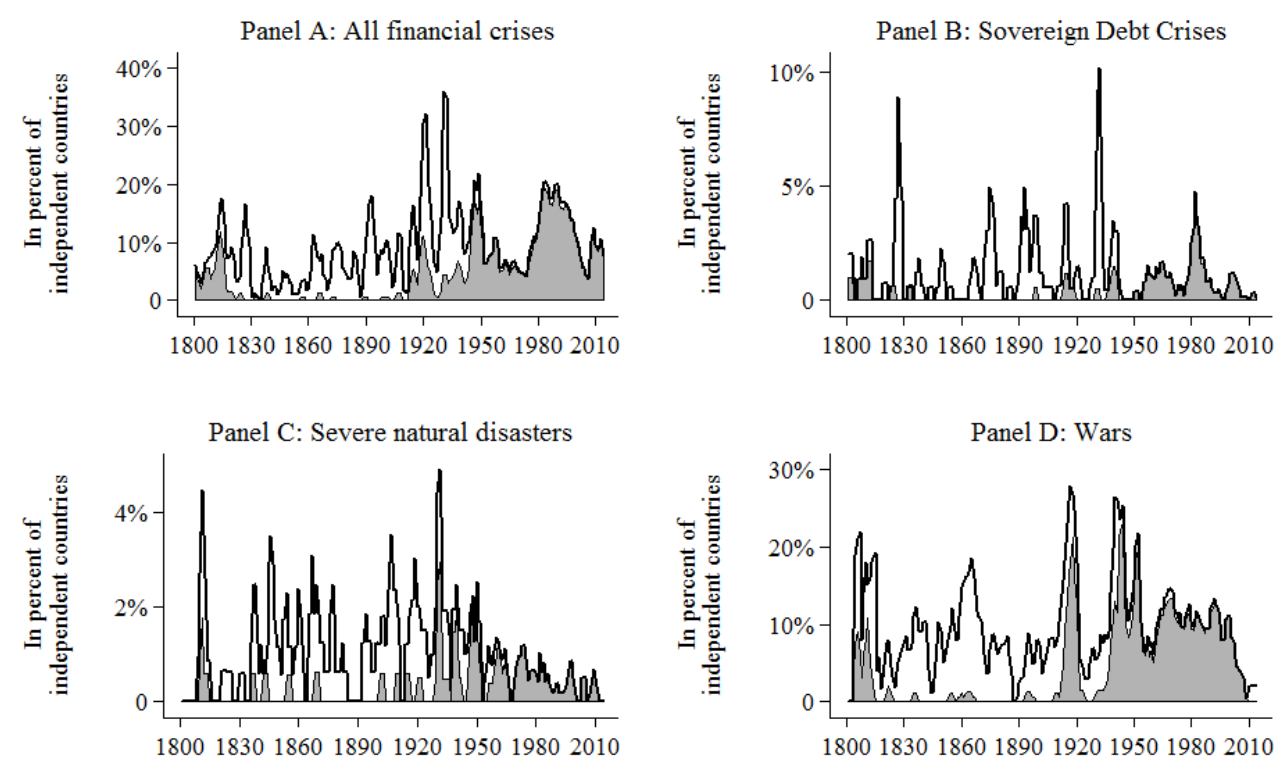

- Share of countries experiencing disasters

Share of countries experiencing disasters and receiving foreign assistance

Note: This figure shows the share of independent countries that experience a disaster (black solid line), as well as the subset of these countries that also receive international official assistance (grey shaded area). The panels differentiate between disaster events: all financial crises (A), debt crises (B), natural disasters (C) and wars (D).

\section{Determinants of rescue lending: Why do governments extend cross-border official loans?}

Why do governments extend cross-border official loans? According to recent theoretical contributions by Tirole (2015), Farhi and Tirole (2018) and Gourinchas, Martin and Messer (2019), a main driver of official rescue lending is the concern about cross-border spillovers. In case of two closely integrated countries, a creditor government has an incentive to assist the country in crisis so as to limit the collateral damage to their own economy. In this view, the rescuer country's solidarity is largely a function of economic self-interest, aimed at reducing the negative externalities stemming from the crisis country. The larger this externality is expected to be, the higher the likelihood and volumes of rescue lending. The intensity of trade and banking linkages should thus help to predict why some governments are willing to assist a crisis country on a large scale, while others choose to abstain.

Here, we bring this theoretical prior to the data. The main hypothesis is that the size of bilateral lending during financial crises increases in the scale of economic and/or financial integration 
between creditor and crisis country. To test this hypothesis, we use our newly assembled bilateral sovereign lending database, which allows us to estimate the determinants of official lending between countries across 200 years. Specifically, we combine our dataset on official bilateral loans with the above described disaster events, focusing on loans extended during the first two years of a war, a major natural disaster, or of banking, sovereign debt and currency crises. ${ }^{4}$

Figure 14 illustrates the dyadic structure of the bilateral lending data. The width of the red connecting lines represents the number of bilateral rescue loans during financial crisis events, wars and natural disasters since 1800 . The graph shows a wide-spanning global network of bilateral financial assistance with the United States and Western Europe being the main creditors.

Figure 14. Bilateral rescue loans in financial crises, wars and natural disasters 1800 to 2015

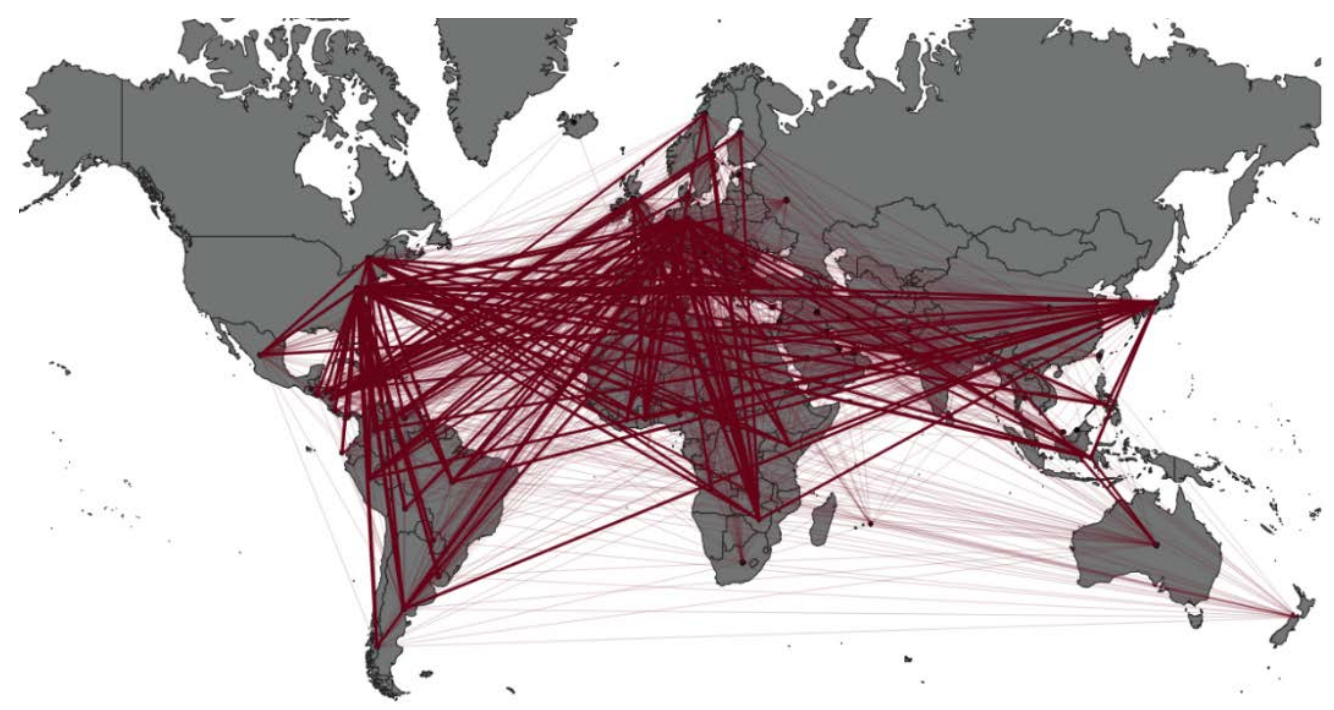

Note: The width of the red lines increases with the number of bilateral rescue loans. Data on bilateral official lending is from our international official lending database (see Section 2 and Appendix III). Data on the incidence of financial crises, wars, and disasters is compiled from various sources (see Section 4.1).

\subsection{Drivers of bilateral rescue lending - descriptives}

In this section we take a preliminary look at the data. We first introduce the key explanatory variables of interest and then examine their correlation with official rescue lending during crises.

To capture the degree of economic and financial interdependence between two countries, we consider two measures. First, bilateral trade exposure, defined as bilateral trade (exports plus imports)

\footnotetext{
${ }^{4}$ This two-year focus is in line with the crisis literature (Kaminsky and Reinhart 1998). The results are similar when considering only loans in the first crisis year or if we use the first three years.
} 
between a creditor and a crisis country, computed as a share of total trade of the creditor economy with the rest of the world. This measure captures the weight of the crisis economy in total external trade of the potential creditor economy. Long-run bilateral trade data comes from the comprehensive TRADHIST project, with bilateral import and export data going back to the early $19^{\text {th }}$ century (Fouquin and Hugot 2016). Second, to capture bilateral financial linkages, we use the BIS International Banking Statistics, which is available from 1984. We calculate bilateral financial exposure analogously to bilateral trade exposure, meaning that we use the bank loan exposure of a potential creditor country towards the crisis country divided by the total bank exposure of the creditor country to the rest of the world. This variable captures the relative importance of the crisis country for the banking and financial sector of the potential creditor country.

Figure 15. Correlates of bilateral lending during disasters- trade and bank linkages
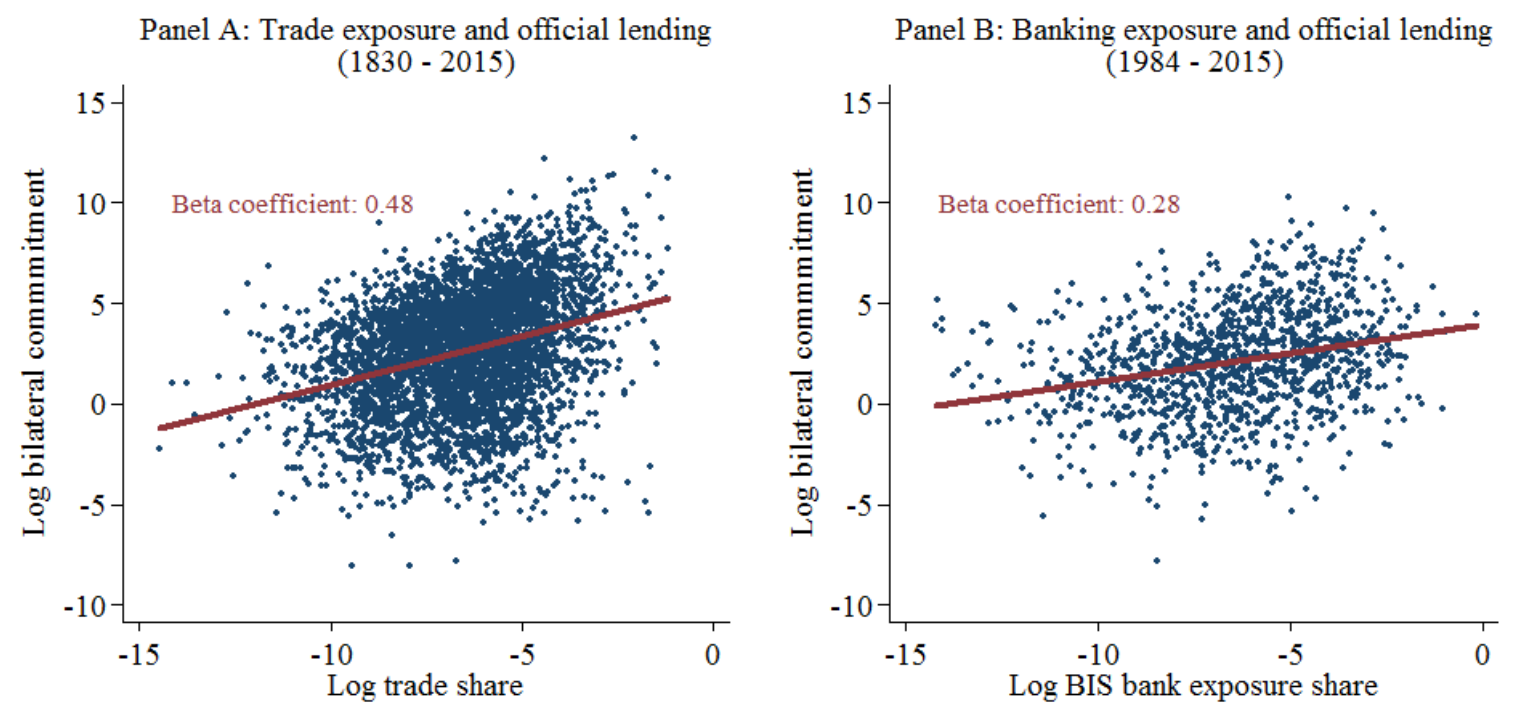

Note: The lines show the fitted values from a regression of log bilateral commitments on the relevant explanatory variable (the corresponding beta coefficient is shown separately). Data on bilateral rescue lending is from the international official lending database (see Section 2 and Appendix III), data on trade and banking exposure is from TRADEHIST (back to 1830) and BIS (back to 1984), respectively.

Figure 15 shows scatter plots of banking and trade exposure between creditor and crisis country with the bilateral loan commitment amount granted by creditor countries in disasters (in constant 2015 US dollars). Each scatter point represents a bilateral loan commitment during disasters since 1830. For illustration, we use natural logarithms. Furthermore, to reduce reverse causality problems, we use pre-crisis trade and banking exposure. Figure 15 also shows fitted values and beta coefficients from a univariate regression of bilateral rescue lending amounts on trade and banking 
exposure, respectively. The figure clearly shows that higher creditor country trade or private financial exposure is associated with higher bilateral commitments in a disaster event.

In addition to financial and economic exposure, we also consider the political allegiance between country pairs. Governments may be more inclined to rescue lending, if the crisis country is politically aligned. We measure this political alignment by the overlap in UN voting behavior between pairs of states, a widely used measure that is available post-WW2 (Bailey, Strezhnev and Voeten, 2017).

Following the literature on international trade, we also consider measures of geographic and cultural proximity. We expect the likelihood of cross-border financial assistance to be higher among countries of the same region and those that share cultural and political origins. This builds on the idea that enforcement is easier and information asymmetries are lower between cultural and geographic neighbors (see e.g. Tirole 2015 or Abraham, Caceles-Poveda, Liu and Marimon 2019). Specifically, we use a measure of geographic distance as well as dummy variables of a shared religion, a shared language and a shared colonial history (from Fouquin and Hugot, 2016).

Figure 16. Correlates of bilateral lending in disasters - geographic and political proximity
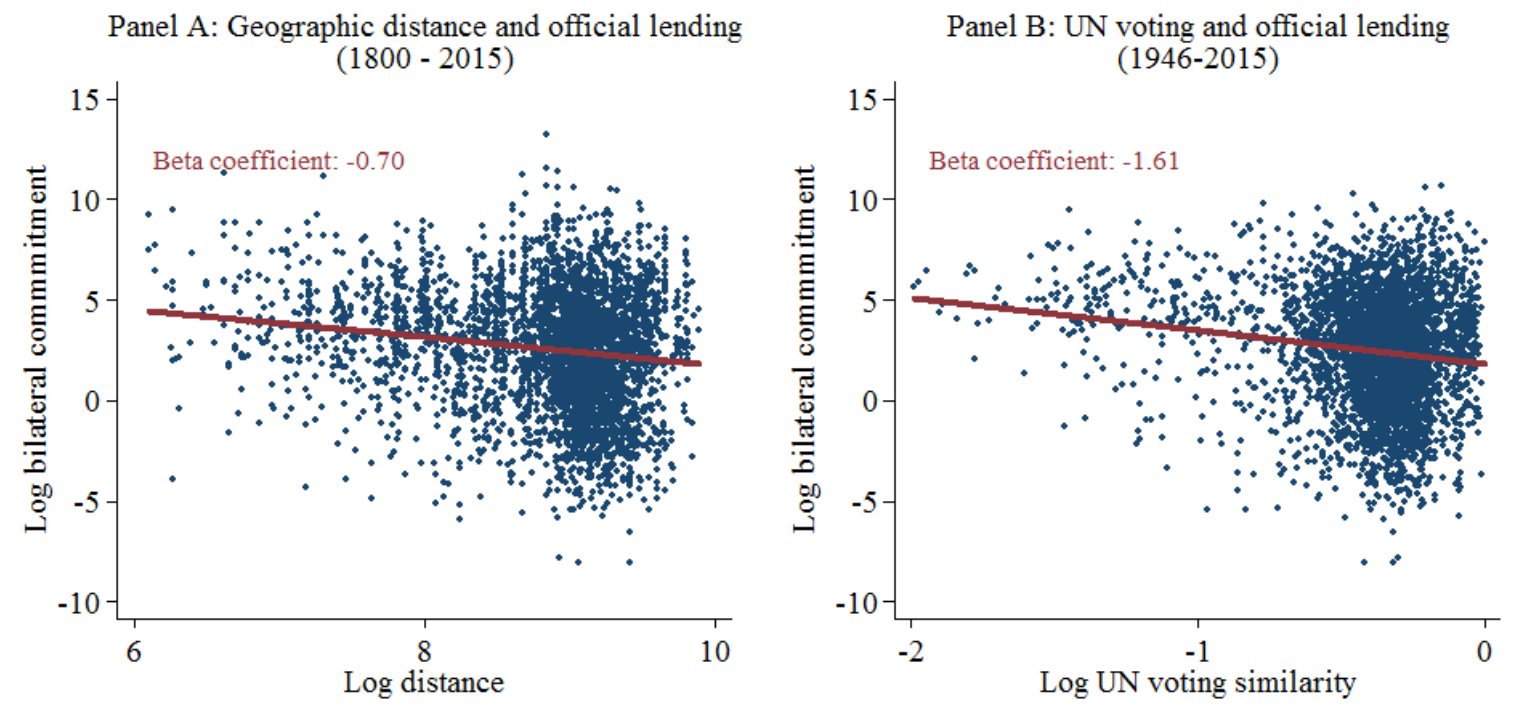

Note: The lines show the fitted values from a regression of log bilateral commitments on the relevant explanatory variable (the corresponding beta coefficient is shown separately). Data on bilateral rescue lending is from the international official lending database (see Section 2 and Appendix II), data on UN voting and distance is from the UN and Fouquin and Hugot (2016), respectively.

Figure 16 plots the measures of joint UN voting and geographic distance against bilateral lending commitments during wars, crises and disasters, again using logs and the pre-disaster values for the explanatory variables. As expected, larger geographic distance between a creditor and a crisis 
country is associated with lower financial commitments in crises (left panel). Moreover, we find a (weak) negative correlation between UN voting similarity and bilateral rescue lending (right panel).

\subsection{A gravity model of bilateral rescue lending}

In this section, we move beyond correlations and estimate an augmented gravity model of bilateral rescue lending. Gravity models posit that bilateral trade between two countries is proportional to their economic size and inversely related to their geographic distance (Head and Mayer 2014). They are a workhorse models of international trade, but have also been found to have high explanatory power for the geography of private international capital flows (e.g. Portes and Rey 2005 and Niepmann 2015). Building on this literature, we apply a gravity model for the context of bilateral official flows. The model takes the following form:

$$
\begin{aligned}
& \ln \left(\text { RescueLoans }_{i, j, t}\right) \\
& =\beta \ln \left(\text { Econ. Exposure }_{i, j, t}\right)+\gamma \ln \left(\text { Distance }_{i, j}\right)+\delta \ln \left(\text { Political Allegiance }_{i, j, t}\right) \\
& +\theta^{\prime} \text { Controls }_{i, j, t}+\vartheta_{i}+\sigma_{t}+\mu_{j}+\varepsilon_{i, j, t}
\end{aligned}
$$

where subscript $i$ refers to the crisis (debtor) country, $j$ denotes a potential creditor country and $t$ is the disaster episode. The dependent variable, RescueLoans $s_{i, j, t}$, captures the size of official bilateral commitments in real US\$ received by debtor country $i$ from creditor country $j$ in crisis episode $t$. More specifically, we include all bilateral official loan commitments extended in the first two years of major wars, natural disasters and financial crises since 1830, as discussed in Section 4.1 and Appendix I.

As explanatory variables, we build on the above cited theory work and include measures of the creditor country's economic and financial exposure to the crisis country. Since bank and trade exposure are very highly correlated we include these variable separately to avoid issues of multicollinearity. In the baseline regressions we use bilateral trade exposure, because the data goes back to the early $19^{\text {th }}$ century, while bilateral bank linkages from the BIS are available only since the 1980s. As discussed above, we also include geographic distance to the crisis country, similarity in UN voting as well as variables for cultural proximity through joint language, joint religion and a shared colonial history. Since these measures of cultural proximity are highly correlated, we only include a dummy for a shared colonial history in our benchmark regressions, but the results do not significantly change, if other measures are used. We also include debtor and creditor fixed effects to account for time-invariant creditor or debtor characteristics and episode fixed effects. These episode fixed effects are disaster-specific, so as to control for time-specific disaster characteristics such as crisis severity. 
For the estimation, we closely follow the established literature and examine both the extensive and intensive margin, which in our case is the occurrence and size of bilateral official rescue lending, respectively. Under heteroscedasticity, OLS estimates of log-linearized models are known to be biased. Furthermore, the large number of zeros in the dependent variable leads to a truncated sample under log-transformation (Head and Mayer 2014). A common solution is to employ a Poisson Pseudo Maximum Likelihood (PPML) estimator that has the desirable properties of being consistent under heteroskedastic error terms and that naturally incorporates zero observations (Head and Meyer 2014). PPML can be used to estimate the parameters of a constant elasticity model in its multiplicative form and thus avoids the dropping of zeros. Santos Silva and Tenreyro (2006) further show that the PPML estimator leads to the same set of first-order conditions as an efficient and consistent non-linear least square estimator. For the PPML estimator to be consistent and efficient, it is therefore not necessary for the data generating process to follow a Poisson likelihood function.

Against this backdrop, our main approach is to estimate Poisson Pseudo Maximum Likelihood models, in order to account for heteroscedasticity and to avoid truncation of the sample. For completeness, we also show results using a simple binary model, in which the dependent variable is a dummy that takes the value of one, if a creditor country extends a rescue loan to the crisis country and that is zero otherwise. Moreover, we run OLS to estimate the log-linearized model with log bilateral commitments as the dependent variable, even though we are aware that this will result in a truncated sample with the above-mentioned bias due to heteroscedasticity. In all three models, robust standard errors are used, clustered at the creditor-debtor dyad level.

Table 5 shows the results of the PPML regressions for the full sample as well as for subsamples in different eras of the international financial system. In line with our main hypothesis, bilateral economic and financial exposure is significantly correlated with bilateral rescue lending across all subsamples, both when using measures of trade and banking linkages. The same is true for political allegiances (UN voting similarity, post-WW2) and for the importance of a shared colonial history. We also find that geographic distance is a statistically significant predictor of bilateral rescue lending. It enters all regressions models with a negative coefficient and thus suggests that informational asymmetries and enforcement issues play an important role in impeding official financial lending in crisis times. 
Table 5: Gravity models of bilateral rescue lending: Full sample (1830-2015) and by era

\begin{tabular}{|c|c|c|c|c|c|}
\hline & \multicolumn{5}{|c|}{ Dep. variable: Bilateral rescue lending } \\
\hline & $\begin{array}{c}\text { Full Sample } \\
1830-2015 \\
\text { (1) }\end{array}$ & $\begin{array}{l}\text { Pre-WWII } \\
1830-1945 \\
\text { (2) }\end{array}$ & $\begin{array}{c}\text { Bretton Woods } \\
1946-1973 \\
\text { (3) }\end{array}$ & $\begin{array}{c}\text { Modern Era } \\
1973 \text { - } 2015 \\
\text { (trade linkages) } \\
\text { (4) }\end{array}$ & $\begin{array}{c}\text { Modern Era } \\
1984 \text { - } 2015 \\
\text { (banking linkages) } \\
\text { (5) }\end{array}$ \\
\hline Trade exposure & $\begin{array}{c}0.34^{* * * *} \\
(0.10)\end{array}$ & $\begin{array}{l}0.99^{*} \\
(0.54)\end{array}$ & $\begin{array}{l}0.32 * * \\
(0.15)\end{array}$ & $\begin{array}{c}0.50^{* * * *} \\
(0.12)\end{array}$ & \\
\hline Financial exposure & & & & & $\begin{array}{c}0.26^{* * *} \\
(0.06)\end{array}$ \\
\hline Distance & $\begin{array}{c}-0.35^{* *} \\
(0.15)\end{array}$ & $\begin{array}{c}-0.95^{* *} \\
(0.48)\end{array}$ & $\begin{array}{c}-0.63^{* *} \\
(0.28)\end{array}$ & $\begin{array}{l}-0.30^{*} \\
(0.18)\end{array}$ & $\begin{array}{c}-0.55^{* * *} \\
(0.17)\end{array}$ \\
\hline UN voting & & & $\begin{array}{c}6.60^{* * * *} \\
(1.45)\end{array}$ & $\begin{array}{c}2.54^{* *} \\
(1.25)\end{array}$ & $\begin{array}{l}5.44 * * \\
(2.41)\end{array}$ \\
\hline (Former) colony & $\begin{array}{c}1.12 * * * \\
(0.29)\end{array}$ & $\begin{array}{c}1.37 * * * \\
(0.46)\end{array}$ & $\begin{array}{c}1.53 * * * \\
(0.34)\end{array}$ & $\begin{array}{c}0.69^{* * *} \\
(0.26)\end{array}$ & $\begin{array}{c}1.18^{* * *} \\
(0.22)\end{array}$ \\
\hline Constant & $\begin{array}{c}9.67 * * * \\
(1.26)\end{array}$ & $\begin{array}{c}7.10 \\
(4.63)\end{array}$ & $\begin{array}{c}8.25^{* * * *} \\
(2.65)\end{array}$ & $\begin{array}{c}0.67 \\
(1.53)\end{array}$ & $\begin{array}{l}-0.43 \\
(1.92)\end{array}$ \\
\hline $\begin{array}{l}\text { Observations } \\
\text { R-squared }\end{array}$ & $\begin{array}{l}15429 \\
0.825\end{array}$ & $\begin{array}{c}449 \\
0.997\end{array}$ & $\begin{array}{l}1736 \\
0.921\end{array}$ & $\begin{array}{l}12042 \\
0.730\end{array}$ & $\begin{array}{l}1283 \\
0.961\end{array}$ \\
\hline Creditor FE & $\checkmark$ & $\checkmark$ & $\checkmark$ & $\checkmark$ & $\checkmark$ \\
\hline Debtor FE & $\checkmark$ & $\checkmark$ & $\checkmark$ & $\checkmark$ & $\checkmark$ \\
\hline Episode FE & $\checkmark$ & $\checkmark$ & $\checkmark$ & $\checkmark$ & $\checkmark$ \\
\hline Controls & $\checkmark$ & $\checkmark$ & $\checkmark$ & $\checkmark$ & $\checkmark$ \\
\hline
\end{tabular}

Note: Poisson Pseudo Maximum Likelihood regressions using gross bilateral commitments during crises, wars and disasters as dependent variable (in real USD.) All explanatory variables enter as pre-crisis values. The models include creditor, debtor and disaster fixed effects. Robust standard errors are clustered at the creditordebtor dyad. ${ }^{* *}, * *$, and $*$ indicate statistical significance at the $1 \%, 5 \%$ and $10 \%$ level. See Table A2 in the Appendix for a list of included countries.

Table 6 confirms the main results by focusing on the post-WW2 sample and comparing the PPML estimation results with those of OLS and Probit models. In all three columns, bilateral trade exposure emerges as a key predictor of official rescue lending during crisis and disasters, both in terms of statistical significance and in terms of coefficient size. At the extensive margin (probit model), an increase in bilateral trade exposure is associated with a statistically significant increase in the likelihood of a rescue loan. In the OLS model, an increase in trade exposure by one percent is reflected in a 0.40 percent increase in real commitment amounts. And finally, in the PPML model that captures both the intensive as well as the extensive margin, the estimated elasticity of rescue lending to bilateral trade exposure is 0.43 and statistically significant. The different models also show similar results with respect to distance, shared culture, and political allegiance (UN general assembly voting). 
Table 6. Gravity models of bilateral rescue lending: Different econometric models

\begin{tabular}{lccc}
\hline \hline & \multicolumn{3}{c}{ Dep. variable: Bilateral rescue lending } \\
& Probit & OLS & PPML \\
& $(1)$ & $(2)$ & $(3)$ \\
\hline Trade exposure & $0.24^{* * *}$ & $0.40^{* * *}$ & $0.43^{* * *}$ \\
& $(0.03)$ & $(0.06)$ & $(0.10)$ \\
Distance & $-0.13^{*}$ & $-0.46^{* * *}$ & $-0.29^{*}$ \\
& $(0.07)$ & $(0.13)$ & $(0.15)$ \\
UN voting & -0.34 & $1.59^{* * *}$ & $3.77^{* * *}$ \\
& $(0.41)$ & $(0.57)$ & $(0.71)$ \\
Former colony & $0.35^{* * *}$ & $1.67^{* * *}$ & $0.92^{* * *}$ \\
& $(0.13)$ & $(0.21)$ & $(0.20)$ \\
Constant & $3.08^{* *}$ & -0.99 & $6.64^{* * *}$ \\
& $(1.30)$ & $(1.23)$ & $(1.17)$ \\
\hline Observations & 13778 & 3639 & 13778 \\
R-squared & & 0.600 & 0.742 \\
Creditor FE & $\checkmark$ & $\checkmark$ & $\checkmark$ \\
Debtor FE & $\checkmark$ & $\checkmark$ & $\checkmark$ \\
Episode FE & $\checkmark$ & $\checkmark$ & $\checkmark$ \\
Controls & $\checkmark$ & $\checkmark$ & $\checkmark$ \\
\hline \hline
\end{tabular}

Note: The dependent variable in the probit model is a dummy variable indicating the provision of a bilateral rescue loan, the dependent variables in the OLS and PPML model are log real bilateral commitments. All explanatory variables enter as pre-crisis values. All three models include creditor, debtor and episode fixed effects. Robust standard errors are clustered at the creditor-debtor dyad. ***, **, and * indicate statistical significance at the $1 \%, 5 \%$ and $10 \%$ level. See appendix table A2 for a list of included countries.

Taken together, our results reveal persistent patterns of financial rescue lending during disasters. The statistical significance and quantitative importance of bilateral trade and financial exposure suggests that official flows follow private flows. Countries seem to be most willing to cooperate financially, when private agents have significant "skin in the game" in the form of real economic or financial exposure to the crisis country. This finding points towards a substantial element of economic self-interest in financial cooperation across all eras of the international financial system. Cooperation is most likely to emerge during contagious crises and between closely integrated economies. A less charitable restatement is that smaller and poorer countries with more limited spillover potential across borders are likely to receive less official finance even if their disasters are just as severe. 
At the same time, cooperation seems to be impeded by informational asymmetries, as the likelihood of rescue lending decreases significantly with higher geographic and cultural distance. Besides economic exposure, political allegiance can help in overcoming these frictions.

\section{Conclusion}

This paper quantifies and studies the scope and determinants of official, sovereign-tosovereign lending over the past two centuries, based on an encompassing new database. We show that cross-border official lending has been an important force in international finance both in the previous two centuries and today. Official lending tends to spike during wars and severe financial crises with the most notable episodes in World Wars 1 and 2, under Bretton Woods and in the 1930s Depression.

Official cross-border loans and bailouts have also become much more institutionalized. Dozens of new official creditor institutions have been created since the 1970s, including, regional development banks. At the same time, bilateral and multilateral institutions lending continue to play an important role while central banks have become much more active again in lending to their counterparts across borders. Few, if any, major military conflicts, systemic financial crises, or natural disasters pass without some form of international official rescue lending.

In the past two decades, official overseas lending has returned with force, with China joining advanced country governments as an active official lender. The size of the post-2008 crisis international bailout packages of Greece, Iceland, Ireland, and Portugal set records (relative to the recipient's GDP or IMF quotas). In its early stages still, official lending during the Covid-19 crisis has already skyrocketed both in the form of various emergency facilities at the IMF and World Bank and swap lines from the Federal Reserve, a replay of the global financial crisis of 2008.

A further key insight from our analysis is that official lending increases with the degree of economic integration. Standard gravity models suggest that economies that are closely interlinked are also more likely to cooperate financially when adversity strikes. At a more general level, the rise in globalization of recent decades occurs alongside a rise in official cross-border finance.

While their character may morph over time, we conclude that official capital flows will remain a central element of the international financial system for decades to come. Against this background, more work is needed to analyze the features of official lending around the world, as well as its determinants and consequences. On determinants, our analysis represents a first step to understand why sovereign nations lend to each other. There are many questions more for future research. What are geopolitical drivers of official lending? What is the role of central bank cross-border lending in 
crisis management and resolution? Should official loans and bailout packages be extended via bilateral, regional or rather multilateral institutions? Also some of the questions addressed in an older literature may warrant revisiting: What are the spillovers between official and private capital flows? What are the effects of policy conditionality that is so often attached to official loans? No doubt the unfolding Covid-19 pandemic will raise a whole new set of questions on the design and efficacy of new crisis lending facilities and official debt relief efforts. 


\section{References}

Accominotti, Olivier, and Barry Eichengreen. 2015. The mother of all sudden stops: capital flows and reversals in Europe, 1919-32. The Economic History Review, 69(2), 469-492.

Aguiar, Mark, and Manuel Amador. 2013. Sovereign Debt: A Review. NBER Working Paper No. 19388.

Alfaro, Laura, Sebnem Kalemli-Ozcan, and Vadym Volosovych. 2014. Sovereigns, Upstream Capital Flows, and Global Imbalances. Journal of the European Economic Association, 12(5), 1240 1284.

Árpád, Ábrahám, Eva Carceles-Poveda, Yan Liu, and Ramon Marimon. 2019. On the optimal design of a Financial Stability Fund. Mimeo.

Bahaj, Saleem, and Ricardo Reis. 2019. Central Bank Swap Lines: Evidence on the Effects of the Lender of Last Resort. IMES Discussion Paper Series 19-E-09.

Bailey, Michael A., Anton Strezhnev, and Erik Voeten. 2017. Estimating Dynamic State Preferences from United Nations Voting Data. Journal of Conflict Resolution, 61(2), 430-456.

Barkbu, Bergljot, Barry Eichengreen, and Ashoka Mody. 2011. International Financial Crises and the Multilateral Response: What the Historical Record Shows. NBER Working Paper No. 17361.

Barro, Robert J. 2006. Rare Disasters and Asset Markets in the Twentieth Century. The Quarterly Journal of Economics, 121(3), 823-866.

Barro, Robert J., and José F. Ursúa. 2008. Macroeconomic Crises since 1870. Brookings Papers on Economic Activity, 39(1), 255-350.

Bordo, Michael D., and Anna J. Schwartz. 1998. Under What Circumstances, Past and Present, Have Country Rescues Been Successful? Journal of International Money and Finance, 18(4), 683708.

Bordo, Michael D., and Anna J. Schwartz. 2001. From the Exchange Stabilization Fund to the International Monetary Fund. NBER Working Paper No. 8100.

Bordo, Michael D., Owen F. Humpage, and Anna J. Schwartz. 2015. The Evolution of the Federal Reserve Swap Lines since 1962. IMF Economic Review, 63(2), 353-372.

Brown, Craig O., and I. Serdar Dinç. 2005. The Politics of Bank Failures: Evidence from Emerging Markets. The Quarterly Journal of Economics, 120(4), 1413-1444.

Bruno, Valentina, and Hyun Song Shin. 2015. Capital flows and the risk-taking channel of monetary policy. Journal of Monetary Economics, 71(C), 119-132.

Calvo, Guillermo, Leonardo Leiderman, and Carmen M. Reinhart. 1993. Capital Inflows and Real Exchange Rate Appreciation in Latin America: The Role of External Factors. IMF Staff Papers, 40(1), 108-151.

Cogan, Jakob K., Ian Hurd, and Ian Johnstone. 2016. The Oxford Handbook of International Organizations. London: Oxford University Press. 
Cooper, Richard, Barry Eichengreen, Gerald Holtham, Robert Putnam, and C. Randall Henning, eds. 1989. Can Nations Agree? Washington D.C.: Brookings Institution Press.

Corsetti, Giancarlo, Aitor Erce, and Timothy Uy. 2017. Official Sector Lending Strategies During the Euro Area Crisis. Cambridge Working Papers in Economics 1730.

Corsetti, Giancarlo, Bernardo Guimaraes, and Nouriel Roubini. 2003. A Model of the IMF's Catalytic Lending. Journal of Monetary Economics, 53(3), 441-471.

Dellas, Harris, and Dirk Niepelt. 2016. Sovereign Debt with Heterogeneous Creditors. Journal of International Economics, 99, 16-26.

Eichengreen, Barry. 1992. Golden Fetters: The Gold Standard and the Great Depression 1919-1939. New York: Oxford University Press.

End, Nicolas, Marina Marinkov, and Fedor Miryugin. 2019. Instruments of Debtstruction: A New Database of Interwar Debt. IMF Working Paper No. 19/226.

Farhi, Emmanuel, and Jean Tirole. 2018. Deadly Embrace: Sovereign and Financial Balance Sheets Doom Loops. Review of Economic Studies, 85(3), 1781-1823.

Feldstein, Martin, ed. 2007. International Economic Cooperation. Chicago: University of Chicago Press.

Fink, Fabian, and Almuth Scholl. 2016. A Quantitative Model of Sovereign Debt, Bailouts and Conditionality. Journal of International Economics, 98, 176-190.

Flores Zendejas, Juan H., and Yann Decorzant. 2015. Going multilateral? Financial markets' access and the League of Nations loans, 1923-8. The Economic History Review, 69(2), 653-678.

Fouquin, Michel, and Jules Hugot. 2016. Two Centuries of Bilateral Trade and Gravity Data: 18272014. CEPII Working Paper No. 14.

Gabaix, Xavier. 2012. Variable Rare Disasters: An Exactly Solved Framework for Ten Puzzles in Macro-Finance. The Quarterly Journal of Economics, 127(2), 645-700.

Glick, Reuven, and Alan M. Taylor. 2010. Collateral Damage: Trade Disruption and the Economic Impact of War. The Review of Economics and Statistics, 92(1), 102-127.

Gourinchas, Pierre-Olivier, and Olivier Jeanne. 2013. Capital Flows to Developing Countries: The Allocation Puzzle. The Review of Economic Studies, 80(4), 1484-1515.

Gourinchas, Pierre-Olivier, Philippe Martin and Todd Messer. 2019. The Economics of Sovereign Debt, Bailouts and the Eurozone Crisis. Mimeo.

Head, Keith, and Thierry Mayer. 2014. Gravity Equations: Workhorse, Toolkit, and Codebook. In G. Gopinath, E. Helpman, and K. Rogoff, eds. Handbook of International Economics, 4, 131195.

Horn, Sebastian, Carmen M. Reinhart, and Christoph Trebesch. 2019. China's Overseas Lending. NBER Working Paper No. 26050.

James, Harold. 1996. International Monetary Cooperation since Bretton Woods. New York: Oxford University Press. 
Kaminsky, Graciela L., and Carmen M. Reinhart. 1999. The Twin Crises: The Causes of Banking and Balance-of-Payments Problems. American Economic Review, 89(3), 473-500.

Keene, Edward. 2012. The Treaty-Making Revolution of the Nineteenth Century. The International History Review, 34(3), 475-500.

Kindleberger, Charles P. 1986. International Public Goods without International Government. American Economic Review, 76(1), 1-13.

Kindleberger, Charles P. 2006. A Financial History of Western Europe. London: Routledge.

Lane, Phillip, and Gian Maria Milesi-Ferretti. 2007. The external wealth of nations mark II: Revised and extended estimates of foreign assets and liabilities, 1970 - 2014. Journal of International Economics, 73(2), 223 - 250.

Lorenzoni, Guido. 2014. International Financial Crises. In G. Gopinath, E. Helpman, and K. Rogoff, eds. Handbook of International Economics, 4, 689-740.

Margold, Stella. 1934. Export Credit Insurance in Europe Today. Washington D.C.: U.S. Government Printing Office.

Marichal, Carlos. 1989. A Century of Debt Crises in Latin America : From Independence to the Great Depression, 1820-1930. Princeton: Princeton University Press.

Martin, Philippe, Thierry Mayer, and Mathias Thoenig. 2005. Make trade not war? The Review of Economic Studies, 75, 865-900.

Meyer, Josefin, Carmen M. Reinhart, and Christoph Trebesch. 2019. Sovereign Bonds since Waterloo. NBER Working Paper No. 25543.

Meyer, Richard H. 1970. Bankers' Diplomacy - Monetary Stabilization in the Twenties. New York: Columbia University Press.

Mitchell, Brian. 2013. International Historical Statistics 1750 - 2010. Basingstoke: Palgrave Macmillan.

Mitchener, Kris J., and Marc D. Weidenmier. 2010. Supersanctions and sovereign debt repayment. Journal of International Money and Finance, 29(1), 19-36.

Morris, Stephen, and Hyun Song Shin. 2006. Catalytic Finance: When Does It Work? Journal of International Economics, 70(1), 161-177.

Niepmann, Friederike. 2015. Banking Across Borders. Journal of International Economics, 96(2), 244-265.

Nurkse, Ragnar. 1944. International Currency Experience. Geneva: League of Nations.

Obstfeld, Maurice, and Kenneth Rogoff. 2000. The Six Major Puzzles in International Macroeconomics: Is There a Common Cause? NBER/Macroeconomics Annual, 15(1), 339390.

Obstfeld, Maurice, Jay C. Shambaugh, and Alan M. Taylor. 2009. Financial Instability, Reserves, and Central bank Swap Lines in the Panic of 2008. American Economic Review, 99, 480-486. 
Obstfeld, Maurice, and Alan M. Taylor. 2004. Global Capital Markets: Integration, Crisis, and Growth. New York: Cambridge University Press.

Portes, Richard, and Hélène Rey. 2005. The Determinants of Cross-Border Equity Flows. Journal of International Economics, 65(2), 269-296.

Reinhart, Carmen M., and Christoph Trebesch. 2015a. The IMF: 70 Years of Reinvention. Journal of Economic Perspectives, 30(1), 3-28.

Reinhart, Carmen M., and Christoph Trebesch. 2015b. The pitfalls of external dependence: Greece, 1829 - 2015. Brookings Papers on Economic Activity, 2, 307-328.

Reinhart, Carmen M., and Kenneth S. Rogoff. 2009. This Time Is Different: Eight Centuries of Financial Folly. Princeton: Princeton University Press.

Reinhart, Carmen M., Vincent Reinhart, and Christoph Trebesch. 2016. Global Cycles: Capital Flows, Commodities, and Sovereign Defaults, 1815-2015. American Economic Review, 106(5), 574580 .

Rey, Hélène. 2015. Dilemma not Trilemma: The Global Financial Cycle and Monetary Policy Independence. NBER Working Paper No. 21162.

Roubini, Nouriel, and Brad Setser. 2004. Bailouts or Bail-Ins? Responding to Financial Crises in Emerging Economies. New York: Peterson Institute for International Economics.

Silva, João M.C. Santos, and Silvana Tenreyro. 2006. The Log of Gravity. The Review of Economics and Statistics, 88(4), 641-658.

Sarkees, Meredith, and Frank Wayman. 2010. Resort to War: 1816 - 2007. Washington D.C.: CQ Press.

Scheubel, Beatrice, and Livio Stracca. 2016. What Do We Know about the Global Financial Safety Net? Rationale, Data and Possible Evolution. ECB Occasional Paper Series No. 177

Schlegl, Matthias, Christoph Trebesch, and Mark L.J. Wright. 2019. The Seniority Structure of Sovereign Debt. NBER Working Paper No. 25793.

Schneider, Christina J., and Jennifer L. Tobin. 2020. The Political Economy of Bilateral Bailouts. International Organization, 74, 1-29.

Silva, João M.C. Santos, and Silvana Tenreyro. 2006. The Log of Gravity. The Review of Economics and Statistics, 88(4), 641-658.

Stallings, Barbara. 1987. Banker to the Third World: US Portfolio Investment in Latin America 19001986. Berkeley: University of California Press.

Stone, Irving. 1999. The Global Export of Capital from Great Britain, 1865-1914: A Statistical Survey. London: Palgrave Macmillan.

Summers, Lawrence. 2000. International Financial Crises: Causes, Prevention, and Cures. American Economic Review, 90(2), 1-16.

Suter, Christian. 1992. Debt cycles in the world economy: foreign loans, financial crises, and debt settlements, 1820-1990. Boulder: Westview. 
Tierney, Michael J., Daniel L. Nielson, Darren G. Hawkins, J. Timmons Roberts, Michael G. Findley, Ryan M. Powers, Bradley Parks, Sven E. Wilson, and Robert L. Hicks. 2011. More Dollars than Sense: Refining Our Knowledge of Development Finance Using AidData. World Development, 39(11), 1891-1906.

Tirole, Jean. 2015. Country Solidarity in Sovereign Crises. American Economic Review, 105(8), 23332363.

Tunçer, Ali Coşkun. 2015. Sovereign Debt and International Financial Control. The Middle East and the Balkans, 1870-1914. London: Palgrave Macmillan. 


\section{Appendix I. Dating disasters since 1800}

Our dataset covers financial crises, military conflicts, and severe natural disasters since 1800 . This appendix describes the relevant definitions and data sources.

\section{Banking, currency and external sovereign debt crises}

Our definition of external financial crisis events follows Reinhart and Rogoff (2009). A currency crisis is defined as an annual depreciation against the relevant anchor currency by 15 percent or more. A banking crisis is defined by events: the occurrence of bank runs that lead to the closure, merging, or take-over of one or more financial institutions, or, in the absence of runs, the closure, merging, takeover, or large-scale government assistance of an important financial institution that marks the start of similar outcomes for other financial institutions. Only systemic (severe) banking crises are included. Finally, an external sovereign debt crisis is defined as the failure of a government to meet a principal or interest payment towards a foreign creditor on the due date.

Determining the duration of a banking crisis is particularly challenging. While dating the start of a banking crisis tends to be easier to discern due to the occurrence of a specific crisis event such as a bank run or intervention, as described. External sovereign debt crises are generally considered to end once final resolution is reached with external creditors (Reinhart and Rogoff, 2009). Figure A1 builds on these definitions and presents the incidence of banking, currency and sovereign debt crises since 1800 by showing the number of countries that experience a currency or banking crisis or are in default (restructuring) on external creditors.

Since that many years and even decades can pass before a country in default reaches a final agreement with external creditors, sovereign defaults can give rise to very long debt crises spells. Similarly, currency crashes can accompany chronically high inflation spells for years. Hence, we limit our focus to new default episodes, i.e. the year, in which a country enters a crisis by defaulting on external debt. Similarly, we date the first year of a currency crash or systemic banking crisis. Figure A2 provides the corresponding incidence graph. 
Figure A1. Varieties of financial crises

Incidence of banking, currency and external sovereign debt crises 1800 - 2015

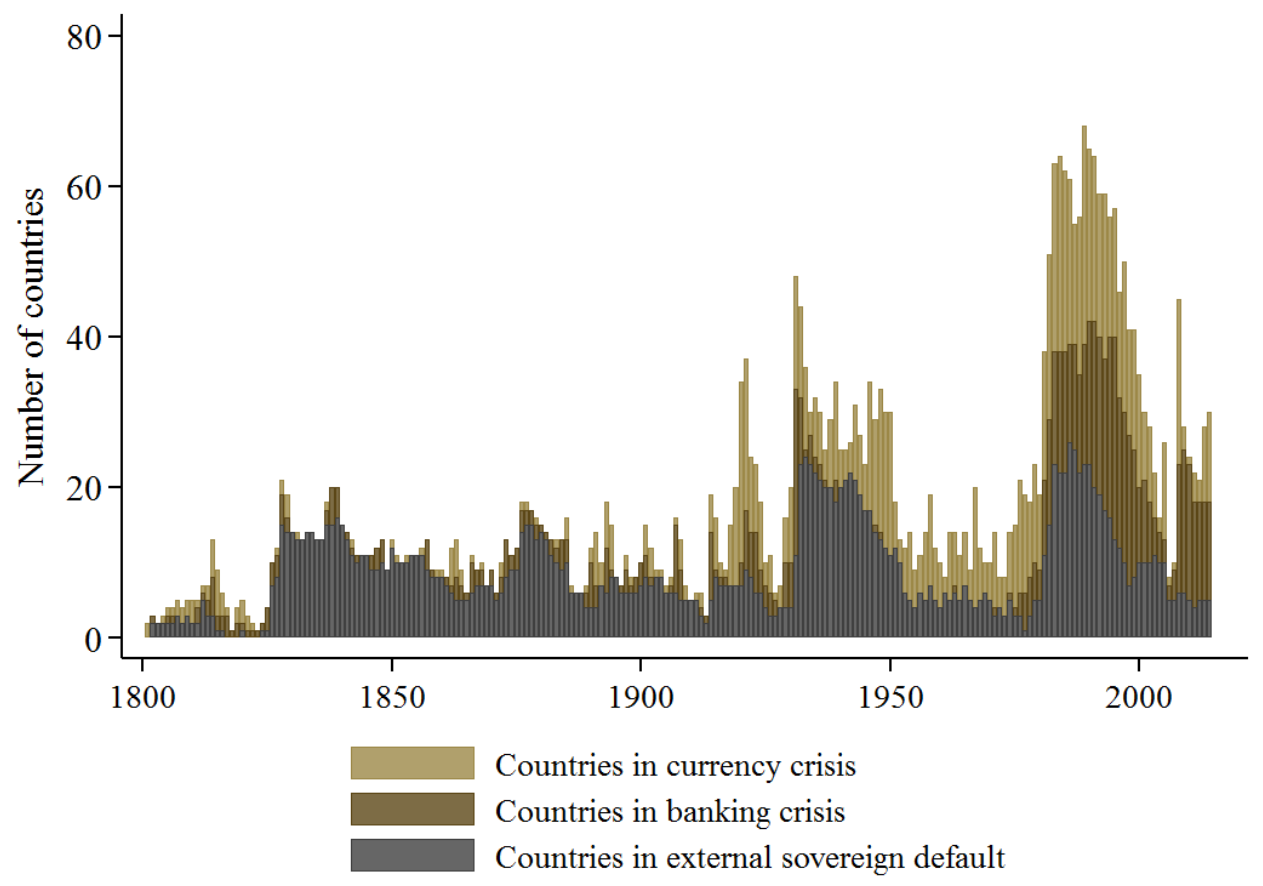

Figure A2. Incidence of new banking, currency and external sovereign debt crises 1800 - 2015

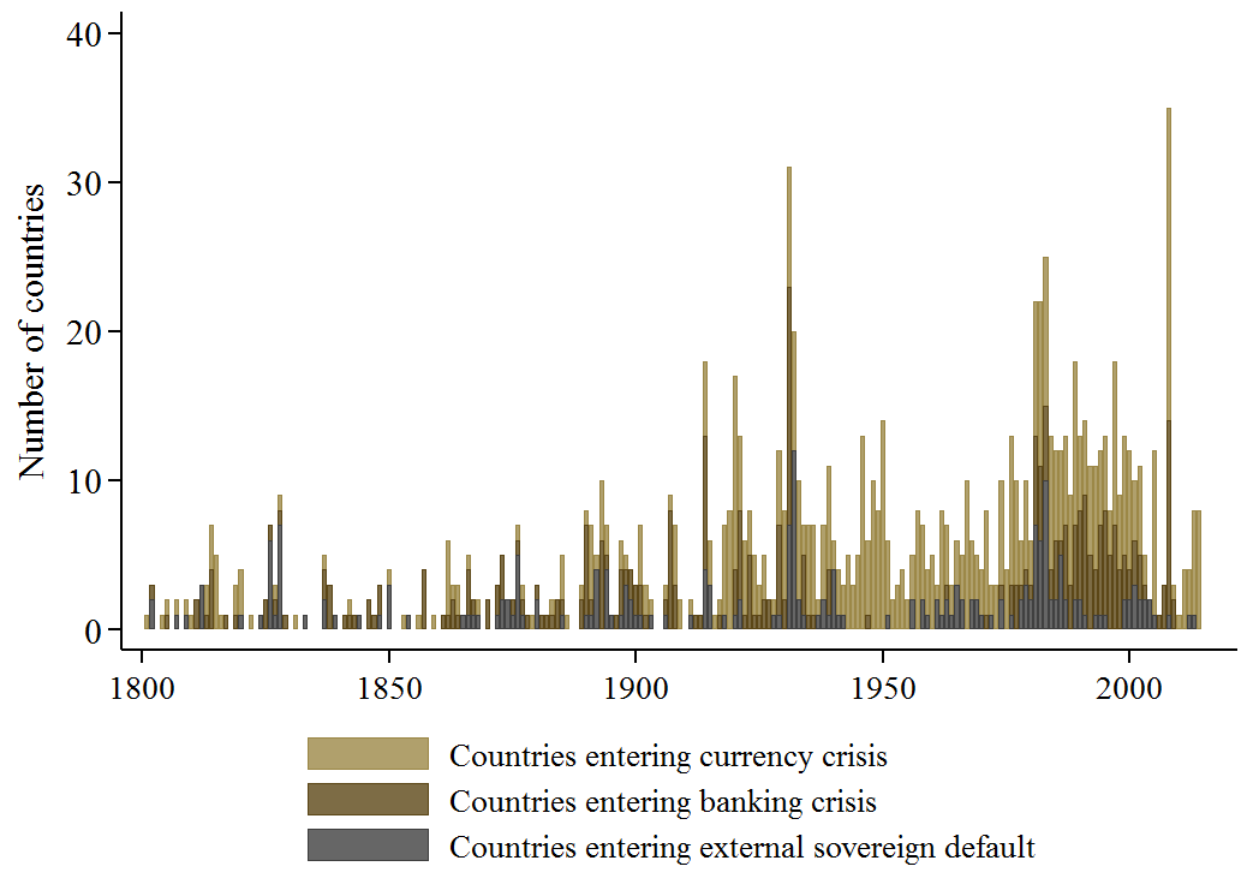

Note: It is common for countries to experience different "varieties" of financial crises in the same year. Data is from Reinhart and Rogoff (2009) and from Meyer, Reinhart and Trebesch (2019). 


\section{Military conflict}

Our dating of wars relies on the Correlates of War project, which defines a war as sustained combat, involving organized armed forces, resulting in a minimum of 1000 battle-related fatalities over the course of a 12 months period (Sarkees and Wayman 2010). The Correlates of War data collection further distinguishes inter-state and intra-state conflict: International or inter-state conflicts are defined as wars between two or more territorial states that are members of the international state system. To the contrary, intra-state (or civil) wars are defined by sustained military combat within a state and with active participation of the national government. In the CoW database, war begins with the onset of sustained military combat and ends with the cessation of sustained military combat. Formal declarations of war and armistice agreements are only used as the beginning and end dates of war if they coincide with the beginning and end of military combat.

Data on inter and intra-state military conflicts is available from the Correlates of War Project since 1816 and until 2010. As the coding of inter- and intra-state military conflicts does not cover the early $19^{\text {th }}$ century and in particular the Napoleonic Wars, we extend coverage back to 1800 . Since data on combat and battle-related fatalities is not readily available, we create a simple dummy variable that indicates formal declarations of war during the Napoleonic and French Revolutionary Wars. To do so, we use the following sources:

Esdaile, Charles. 2007. Napoleon's Wars: An international history, 1803 - 1815. Penguin: London.

Fermont-Barnes, Gregory. 2006. The Encyclopedia of the French Revolutionary and Napoleonic Wars: A Political, Social and Military History. ABC Clio: Santa Barbara.

Gibler, Douglas. 2008. International Military Alliances 1648 - 2008. CQ Press: Washington DC.

Figure A3 shows the number of countries involved in inter- and intra-state military conflicts in each year since 1800 . 
Figure A3. Incidence of military conflicts 1800 - 2010

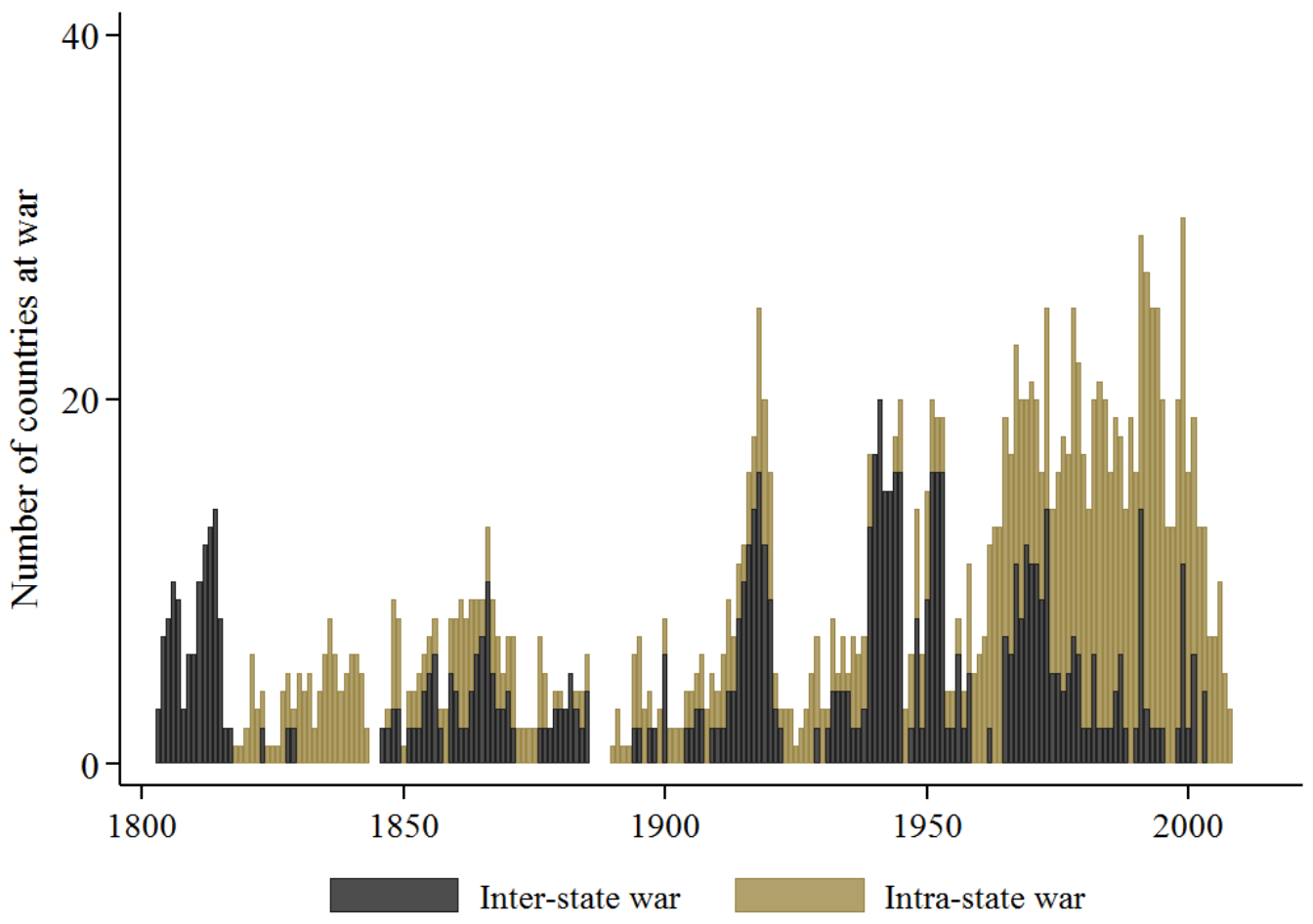

Note: See text for definition and sources.

\section{Natural disasters}

The key building block of this data is the EM-DAT International Disaster Database that provides information on the occurrence, material damage and fatalities of several thousand disasters since 1900. The EM-DAT database includes data on a variety of disastrous events: geophysical (earthquakes and volcano eruptions), meteorological (extreme temperatures and storms), hydrological (floods and landslides), climatological (droughts, famines and wildfires) and biological such as epidemics.

Extending the coverage to the $19^{\text {th }}$ century poses a variety of challenges given that coverage falls far short of modern standards. Our primary source for the years from 1800 to 1900 is the US National Center for Environmental Information that offers data on the occurrence of earthquakes, volcano eruptions, floods, tsunamis and storms. In ongoing data collection, we supplement this data with sources that document the incidence of famines and epidemics in the $19^{\text {th }}$ century. These include:

Alfani, Guido, and Cormac Ó Gráda. 2018. The timing and causes of famines in Europe. Nature Sustainability 1: 283-288. 
Alfani, Guido, and Cormac Ó Gráda, eds. 2017. Famine in European History. Cambridge University Press: Cambridge.

De Waal, Alex. 2018. Mass Starvation: The History and Future of Famines. Polity Press: Cambridge MA.

Hays, J. 2005. Epidemics and Pandemics: Their Impact on Human History. ABC Clio: Santa Barbara.

Hays, J. 2009. The Burdens of Disease: Epidemics and Human Responses in Western History. Rutgers University Press: New Brunswick NJ.

O’Grada, Garcia. 2009. Famine: A Short History. Princeton University Press: Princeton.

Figure A4 presents the incidence of natural disasters and the associated fatalities since 1800 . Casualties from natural disasters are dominated by major famines such as Europe's year without a summer in 1816, the Great Irish Potato Famine in the late 1840s or the famines associated with China's Great Leap Forward in the late 1950s. The number of identified disaster events shows a pronounced increase particularly after World War II. Rather than reflecting structural trends in the frequency of disasters, this shift is driven by the improvement in coverage and reporting; the time series underscore that our log of disaster events in the $19^{\text {th }}$ and early $20^{\text {th }}$ century is far from complete.

However, as we are primarily interested in severe natural disasters that may warrant international assistance, incomplete coverage during the $19^{\text {th }}$ century is not a major concern. In effect, it raises the issue that for the post-WW2 era we need to restrict the log the more severe disasters. To winnow the event log, we match our list of natural disasters with population data from Mitchell (2007) and restrict our coverage to those natural disasters where the loss of life is at least 0.1 percent of the population of the affected country. This filter yields 108 severe natural disasters over the course of the past 200+ years.

While the timing of a natural disaster is straight-forward in the cases of earthquakes, floods or hurricanes, it is more challenging to accurately date the duration of famines and epidemics. For these cases, we follow the same approach as we do for financial crises and focus on the initial epidemic or famine year. 
Figure A4. Incidence of natural disasters 1800 - 2015

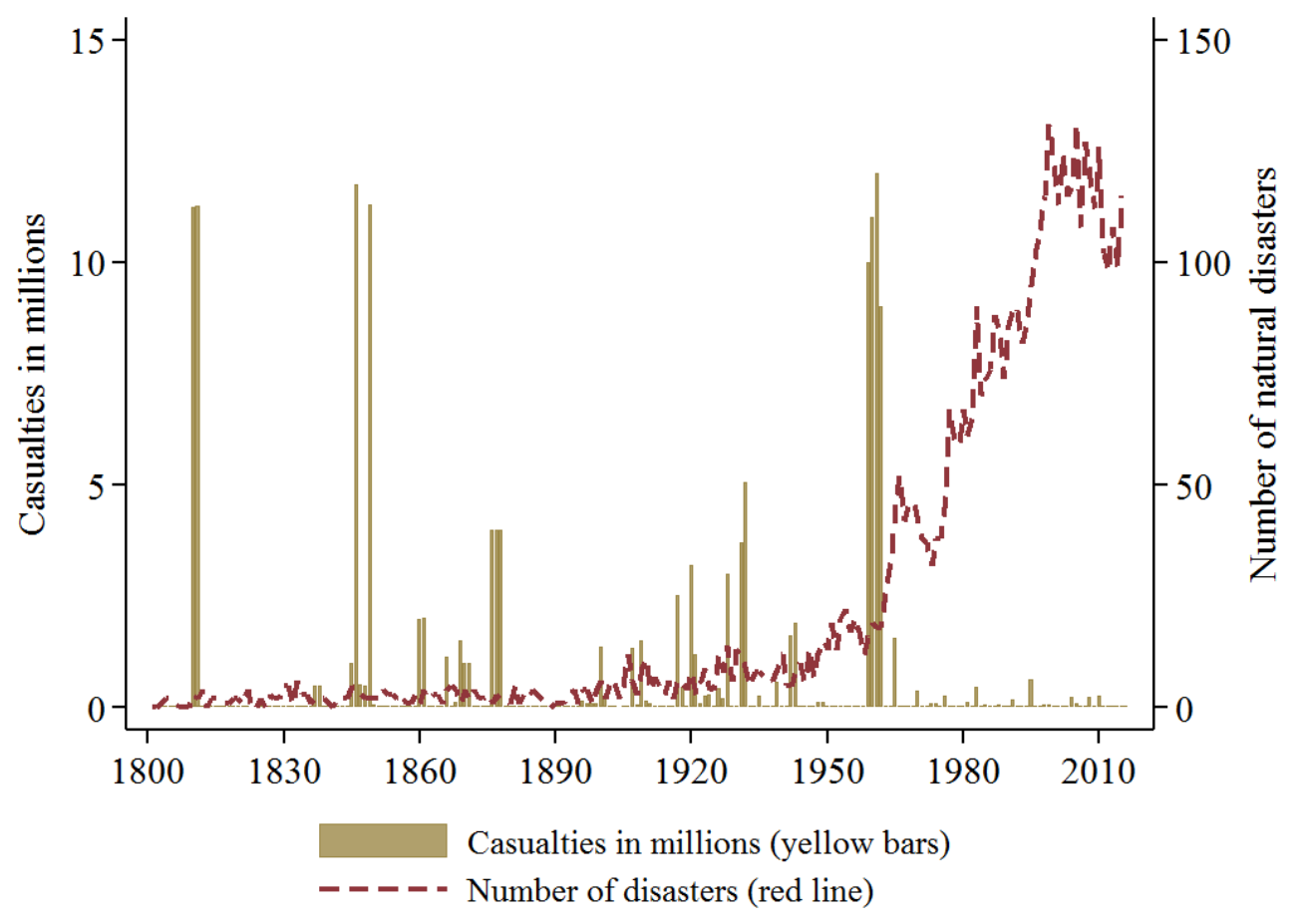

Sources: Multiple sources (see text). 


\section{Appendix II. Country sample for regression analysis}

Table A1. Country sample for regression analysis

\begin{tabular}{lll}
\hline \hline Algeria & Ghana & Peru \\
Angola & Greece & Philippines \\
Argentina & Guatemala & Poland \\
Australia & Honduras & Portugal \\
Belgium & Hungary & Romania \\
Bolivia & Iceland & Russia \\
Brazil & India & Singapore \\
Canada & Indonesia & South Africa \\
Central African Republic & Italy & South Korea \\
Chile & Japan & Spain \\
China & Kenya & Sri Lanka \\
Colombia & Malaysia & Thailand \\
Costa Rica & Mauritius & Tunisia \\
Cote d'Ivoire & Mexico & Turkey \\
Dominican Republic & Morocco & United Kingdom \\
Ecuador & Myanmar & United States of America \\
Egypt & Netherlands & Uruguay \\
El Salvador & Nicaragua & Venezuela \\
Finland & Nigeria & Zambia \\
France & Panama & Zimbabwe \\
Germany & Paraguay & \\
\hline \hline
\end{tabular}




\section{Appendix III. Construction of the International Official Lending database}

Definition of official sovereign lending: Our database provides data on official loans, grants and guarantees by bilateral and multilateral official creditors since 1790 . Note that we do not attempt to cover official transfers resulting from indemnity and reparation payments. While reparation payments have been sizable at different points of history, we do not include them in our dataset, as they are not based on the same consensual legal basis as credits, grants and guarantees.

Our database is spliced together from hundreds of different sources that fall into four main categories: (i) International Treaties and Financial Agreements; (ii) Reports and budget plans of creditor and debtor institutions, both published and from archives; (iii) Information on official lending collected by international organizations, most importantly the Debtor Reporting System (DRS) of the World Bank and the Creditor Reporting System (CRS) of the OECD's Development Assistance Committee (DAC); (iv) Information on official lending collected by modern and historic academic research.

In the following, we list the sources used to construct the database and structure them by the four main eras covered: (i) The long 19th century (1790 to WW2), (ii) the Inter-War Period, (iii) the post-World War II and Bretton Woods era and (iv) the modern era (1970 - 2015), for which data is more readily available from international organizations. Additional creditor-specific sources that have been used for more than one historic era are listed separately by creditor country and organization (v).

\section{The Long $19^{\text {th }}$ Century: $1790-1914$}

Our dataset for the 19th century is mainly based on international treaty series. We search all available treaty collections for bilateral credit and subsidy agreements and code all available information on these financial transactions. The resulting dataset therefore consists of loan-level information on loans, grants and guarantees extended by the United Kingdom, France, Germany, Italy, Russia, AustriaHungary as well as various smaller states. We supplement this series with information from investor manuals and statistical year books as well as dozens of country specific resources, in particular budget plans and national accounts. For lending by central banks, we have made use of existing research on

central bank cooperation during the $19^{\text {th }}$ century and on archival research at the Bank of England and the Banque de France. 


\section{General Treaty Series}

Bevans, Charles. Various Years. Treaties and Other International Agreements of the United States of America. Washington D.C.: Department of State.

De Martens, Georg Frederic. Various Years. Recueil Des Principaux Traites d'Alliance, de Paix, de Treve, de Neutralite, de Commerce, de Limites, d'Echange et des plusieurs autres actes servant a la connaissance des relations etranges des puissances et etats de l'Europe. Gottingue: Libraire de Dieterich.

De Martens, Georg Frederic, and de Martens, Charles. Various Years. Recueil Des Principaux Traites d'Alliance, de Paix, de Treve, de Neutralite, de Commerce, de Limites, d'Echange et des plusieurs autres actes servant a la connaissance des relations etranges des puissances et etats de l'Europe. Gottingue: Libraire de Dieterich.

De Martens, Georg Frederic, and Saalfeld, Frederic. Various Years. Recueil Des Principaux Traites d'Alliance, de Paix, de Treve, de Neutralite, de Commerce, de Limites, d'Echange et des plusieurs autres actes servant a la connaissance des relations etranges des puissances et etats de l'Europe. Gottingue: Libraire de Dieterich.

De Martens, Georg Frederic, and Murhard, Frederic. Various Years. Recueil Des Principaux Traites d'Alliance, de Paix, de Treve, de Neutralite, de Commerce, de Limites, d'Echange et des plusieurs autres actes servant a la connaissance des relations etranges des puissances et etats de l'Europe. Gottingue: Libraire de Dieterich.

Hopf, Jules. Various Years. Noveau Recueil Generals Des Traites et Autres Actes Relatifs aux Rapport de Droit International. Gottingue: Libraire de Dieterich.

Murhard, Frederic. Various Years. Noveau Recueil Generals Des Principaux Traites, Conventions et Autres Transactions Remarquables. Gottingue: Libraire de Dieterich.

Samwer, Charles, and Hopf, Jules. Various Years. Noveau Recueil Generals Des Traites et Autres Actes Relatifs aux Rapport de Droit International. Gottingue: Libraire de Dieterich.

Samwer, Charles. Various Years. Noveau Recueil Generals Des Principaux Traites, Conventions et Autres Transactions Remarquable. Gottingue: Libraire de Dieterich.

Stoerk, Felix. Various Years. Noveau Recueil Generals Des Traites et Autres Actes Relatifs aux Rapport de Droit International. Leipzig: Libraire Dieterich.

Triepel, Heinrich. Various Years. Noveau Recueil Generals Des Traites et Autres Actes Relatifs aux Rapport de Droit International. Leipzig: Libraire Dieterich.

De Martens, Georg Frederic. Various Years. Recueil des Traites et Conventions conclus par la Russie avec les Puissances Etrangeres. St. Petersburg: Imprimerie du Ministere des vois de communication.

De Clercq, M. Jules. Various Years. Recueil des Traites de la France. Paris: Archives Diplomatiques.

United Kingdom Foreign Office. Various Years. British and Foreign State Papers. London: Her Majesty's Stationary Office.

Annual Reports and Statistical Compendia

Clarke, Hyde. 1878. Sovereign and Quasi Sovereign States: Their Debts to Foreign Countries. Journal of the Statistical Society 51 (2): 299 - 347.

Fenn, Charles. Various years. Fenn's compendium of the English and foreign funds, debts and revenues of all nation. London: E. Wilson. 
Fortune, Thomas. Various years. Fortune's Epitome of the Stock and Public Funds. London: Boosey \& Sons.

Kimber, Albert. 1922. Kimber's Records of Government Debts and other Foreign Securities. New York: A. W. Kimber \& Company.

$\underline{\text { Secondary sources }}$

Ahrens, Gerhard. 1986. Krisenmanagement 1857 - Staat Und Kaufmannschaft in Hamburg Während Der Ersten Weltwirtschaftskrise. Hamburg: Verein für Hamburgische Geschichte.

Bordo, Michael D, and Anna J Schwartz. 1999. Under What Circumstances, Past and Present, Have International Rescues of Countries in Financial Distress Been Successful? Journal of International Money and Finance 18 (4): 683 - 708.

Esteves, Rui, and Ali Tuncer. 2014. Feeling the Blues. Moral Hazard and Debt Dilution in Eurobonds Before 1914. CEPR Discussion Paper 9860.

Flandreau, Marc. 1997. Central bank Cooperation in Historical Perspective : A Sceptical View. The Economic History Review 50 (4): 735-63.

Kindleberger, Charles. 1984. A Financial History of Western Europe. London: Routledge.

Mitchener, Kris J. and Marc Weidenmier. 2010. Supersanctions and Sovereign Debt Repayment. Journal of International Money and Finance 29 (1): 19 - 36.

\section{World Wars I and II and the Interwar Period: 1914 - 1945}

Official lending surged with the onset of World War I and its immediate aftermath. Debts owed to official creditors remained high throughout the 1920s and 1930s. This phenomenon was documented in policy reports by official institutions, in investor manuals and in the writings of contemporaneous observers. Our time-series splices together all these sources and supplements them with credit agreements from international treaty series and creditor country budget plans. For central banks we again make use of annual reports, existing academic work and archival research.

\section{Treaty Series, Annual Reports and Statistical Compendia}

Bank for International Settlements. Various Years. Annual Report. Basel: Bank for International Settlements.

League of Nations. 1936. Enquiry into Clearing Agreements. Geneva: League of Nations.

League of Nations. 1943. Relief Deliveries and Relief Loans 1919-1923. Geneva: League of Nations.

League of Nations. Various Years. League of Nations Treaty Series. Geneva: League of Nations.

League of Nations. 1943. Europe's Capital Movements 1919-1932: A Statistical Note. Geneva: League of Nations.

Moody's. Various Years. Moody's Manual of Investments - American and Foreign. New York: Moody's Investor Service. 
United Nations. 1946. International Capital Movement during the Inter-War Period. United Nations Publication No. 1949.II.D.2.

\section{$\underline{\text { Secondary sources }}$}

Andersen, Poul N. 1946. Bilateral Exchange Clearing Policy. London: Oxford University Press.

Clarke, Stephen. 1967. Central bank Cooperation 1924-1931. New York: Federal Reserve Bank of New York.

Eichengreen, Barry. 1992. Golden Fetters: The Gold Standard and the Great Depression 1919 - 1939. New York: Oxford University Press.

Fisk, Harvey. 1924. The Inter-Ally Debts 1914 - 1923. New York: Bankers Trust Company.

Flores Zendejas, Juan, and Yann Decorzant. 2016. Going Multilateral? Financial Markets' Access and the League of Nations Loans, 1923 - 1928. Economic History Review 2: 653-78.

Gordon, Margaret. 1941. Barriers to World Trade. New York: MacMillan.

Margold, Stella. 1934. Export Credit Insurance in Europe today. Washington D.C.: Government Printing Office.

Meyer, Richard Hemming. 1970. Bankers' Diplomacy - Monetary Stabilization in the Twenties. New York: Columbia University Press.

Moulton, Harold G., and Leo Pasvolsky. 1932. War Debts and World Prosperity. Washington D.C.: Brookings Institution.

Myers, Margaret. 1945. The League Loans. Political Science Quarterly 60 (4): 492-526.

Neal, Larry. 1979. The Economics and Finance of Bilateral Clearing Agreements: Germany, 1934-8. The Economic History Review 32 (3): 391-404.

Reinhart, Carmen, and Christoph Trebesch. 2016. Sovereign Debt Relief and Its Aftermath. Journal of the European Economic Association 14 (1): 215-51.

Ritschl, A O. 2001. Nazi Economic Imperialism and the Exploitation of the Small: Evidence from Germany's Secret Foreign Exchange Balances, 1938-1940. Economic History Review 54 (2): $324-45$.

Strachan, Hew. 2004. Financing the First World War. New York: Oxford University Press.

Thomas, Hugh. 1961. The Spanish Civil War. New York: Modern Library.

\section{Post World War II and Bretton Woods: 1945 - 1973}

Our collection of post-WW2 loans and grants builds on a large number of published and unpublished reports by the BIS, the IBRD, Moody's, the OEEC (renamed to OECD in 1961) and the UN. All of the reports listed in the following are available in the on-site or digital archives of these institutions. For ongoing data collection on cross-border central bank lending, we make use of the secondary literature and archival research at the Federal Reserve and the BIS. 


\section{Main Sources}

Andersen, Svend, and James Lynch. 1949. Summary Review of the External Debt of the United Kingdom. Report No. E 67A. Washington D.C.: International Bank for Reconstruction and Development.

Andersen, Svend, James Lynch, and William Pollock. 1949. The External Debt of Ecuador. Report No. E 66. Washington D.C.: International Bank for Reconstruction and Development.

Andersen, Svend, Martin Rosen, and Alexander Stevenson. 1947. Possibility of Foreign Lending by Countries other than the U.S. in the immediate Future. Report No. ERM 82. Washington D.C.: International Bank for Reconstruction and Development.

Bank for International Settlements. 1945 - 1973. Annual Report. Basel: Bank for International Settlements.

Beaufort, Carel de. 1953. Summary of the External Debt of Japan. Report No. EC 14. Washington D.C.: International Bank for Reconstruction and Development.

Beaufort, Carel de. 1953. Summary of the External Debt of West Germany. Report No. EC 18. Washington D.C.: International Bank for Reconstruction and Development.

Fraser, William. 1951. The History and Present Position of the External Debt of the Dominican Republic. Report No. E 137. Washington D.C.: International Bank for Reconstruction and Development.

Fraser, William. 1951. The External Debt of the Kingdom of Denmark. Report No. E 147e. Washington D.C.: International Bank for Reconstruction and Development.

Gaiola, Nicola. 1955. Summary of the External Public Debt of Peru. Report No. EC 46. Washington D.C.: International Bank for Reconstruction and Development.

Huang, Andrew. 1950. Public External Debt of the Belgium and Luxembourg. Report No. E 105. Washington D.C.: International Bank for Reconstruction and Development.

Huang, Andrew. 1950. Preliminary Survey of the External Debt of France. Report No. E 90. Washington D.C.: International Bank for Reconstruction and Development.

Huang, Andrew. 1950. Public External Debt of Ethiopia. Report No. E 107. Washington D.C.: International Bank for Reconstruction and Development.

Huang, Andrew. 1950. Public External Debt of Indonesia. Report No. E 119. Washington D.C.: International Bank for Reconstruction and Development.

Huang, Andrew. 1950. Preliminary Review of The External Debt of Iceland. Report No. E 126. Washington D.C.: International Bank for Reconstruction and Development.

Huang, Andrew. 1950. Public External Debt of Ceylon. Report No. E 129. Washington D.C.: International Bank for Reconstruction and Development.

Huang, Andrew. 1950. The External Debt of Costa Rica. Report No. E 130. Washington D.C.: International Bank for Reconstruction and Development.

Huang, Andrew. 1951. Public External Debt of the Belgian Congo. Report No. E 154. Washington D.C.: International Bank for Reconstruction and Development.

Huang, Andrew. 1951. Review of the External Debt of Iceland. Report No. E 170. Washington D.C.: International Bank for Reconstruction and Development. 
Huang, Andrew. 1952. The External Debt of Nicaragua. Report No. E 224. Washington D.C.: International Bank for Reconstruction and Development.

Huang, Andrew. 1952. Summary of the External Debt of Thailand. Report No. EC 1. Washington D.C.: International Bank for Reconstruction and Development.

Huang, Andrew. 1952. Public External Debt of Luxembourg. Report No. EC 4. Washington D.C.: International Bank for Reconstruction and Development.

Huang, Andrew. 1954. The Public External Debt of Austria. Report No. EC 26. Washington D.C.: International Bank for Reconstruction and Development.

Huang, Andrew. 1954. The External Debt of Ethiopia. Report No. EC 27. Washington D.C.: International Bank for Reconstruction and Development.

Huang, Andrew. 1954. External Public Debt of Greece. Report No. EC 28. Washington D.C.: International Bank for Reconstruction and Development.

Huang, Andrew. 1954. The Long-Term Public External Debt of Belgium and the Belgian Congo. Report No. EC 34. Washington D.C.: International Bank for Reconstruction and Development.

Huang, Andrew. 1954. The External Public Debt of Luxembourg. Report No. EC 38a. Washington D.C.: International Bank for Reconstruction and Development.

Huang, Andrew. 1955. The Long-Term Public External Debt of Belgium and the Belgian Congo. Report No. EC 39. Washington D.C.: International Bank for Reconstruction and Development.

Huang, Andrew. 1956. A Preliminary Review of the External Public Debt of India. Report No. EC 51. Washington D.C.: International Bank for Reconstruction and Development.

Huang, Andrew. 1956. Public External Debt of Indonesia. Report No. EC 54. Washington D.C.: International Bank for Reconstruction and Development.

IBRD. 1955. Summary of the External Public Debt of Norway. Report No. EC 42. Washington D.C.: International Bank for Reconstruction and Development.

IBRD. 1955. The External Debt of Italy. Report No. EC 44. Washington D.C.: International Bank for Reconstruction and Development.

IBRD. 1958. The External Public Debt of Yugoslavia. Report No. EA 84a. Washington D.C.: International Bank for Reconstruction and Development.

Larsen, Harold. 1949. External Credit of Brazil. Report No. E 38/49. Washington D.C.: International Bank for Reconstruction and Development.

Lynch, James. 1950. The History and Present Position of the External Debt of Bolivia. Report No. E 95. Washington D.C.: International Bank for Reconstruction and Development.

Lynch, James and W.M. Gilmartin. 1948. Honduras' External Debt History. Report No. ERM 63. Washington D.C.: International Bank for Reconstruction and Development.

Lynch, James. 1948. Columbia's External Debt History. Report No. ERM 122. Washington D.C.: International Bank for Reconstruction and Development.

Lynch, James. 1948. Finland's External Public Debt History. Report No. ERM 128. Washington D.C.: International Bank for Reconstruction and Development.

Lynch, James. 1949. Peru's External Public Debt History. Report No. E 6. Washington D.C.: International Bank for Reconstruction and Development. 
Lynch, James. 1949. Mexico's External Public Debt, Economic and Financial Causes of Debt and Debt Adjustment Plans. Report No. E 11. Washington D.C.: International Bank for Reconstruction and Development.

Lynch, James. 1949. External Debt of Chile. Report No. E 32. Washington D.C.: International Bank for Reconstruction and Development.

Lynch, James. 1949. Turkey's External Public Debt History. Report No. E 36/49. Washington D.C.: International Bank for Reconstruction and Development.

Lynch, James. 1950. The History and Present Position of the External Debt of Bolivia. Report No. E 95. Washington D.C.: International Bank for Reconstruction and Development.

Lynch, James. 1950. The History and Present Position of the External Debt of Colombia. Report No. E 96. Washington D.C.: International Bank for Reconstruction and Development.

Lynch, James. 1950. The External Debt of Italy. Report No. E 100. Washington D.C.: International Bank for Reconstruction and Development.

Lynch, James. 1949. The External Debt of Uruguay. Report No. E 62. Washington D.C.: International Bank for Reconstruction and Development.

Lynch, James. 1950. External Debt of the Union of South Africa. Report No. E 108a. Washington D.C.: International Bank for Reconstruction and Development.

Lynch, James. 1950. The External Debt of the Netherlands. Report No. E 110. Washington D.C.: International Bank for Reconstruction and Development.

Lynch, James. 1950. The External Debt of Brazil. Report No. E 120. Washington D.C.: International Bank for Reconstruction and Development.

Lynch, James. 1951. Summary of the External Debt of Colombia. Report No. E 150. Washington D.C.: International Bank for Reconstruction and Development..

Lynch, James. 1951. Summary of the External Debt of Panama. Report No. E 160. Washington D.C.: International Bank for Reconstruction and Development.

Lynch, James. 1951. The External Debt of Cuba. Report No. E 164. Washington D.C.: International Bank for Reconstruction and Development.

Lynch, James. 1951. The External Debt of Paraguay. Report No. E 166. Washington D.C.: International Bank for Reconstruction and Development.

Lynch, James. 1951. The External Debt of Egypt. Report No. E 168. Washington D.C.: International Bank for Reconstruction and Development.

Lynch, James. 1951. Summary of the External Debt of Paraguay. Report No. E 198. Washington D.C.: International Bank for Reconstruction and Development.

Lynch, James. 1952. The External Public Debt of Peru. Report No. E 216. Washington D.C.: International Bank for Reconstruction and Development.

Lynch, James. 1952. Summary of the External Debt of Chile. Report No. E 225. Washington D.C.: International Bank for Reconstruction and Development.

Lynch, James. 1952. The External Public Debt of Mexico. Report No. E 236. Washington D.C.: International Bank for Reconstruction and Development.

Lynch, James. 1952. Summary of the External Debt of the Netherlands. Report No. EC 2. Washington D.C.: International Bank for Reconstruction and Development. 
Lynch, James. 1953. Summary of the External Public Debt of Turkey. Report No. EC 20a. Washington D.C.: International Bank for Reconstruction and Development.

Lynch, James. 1953. The External Public Debt of Uruguay. Report No. EC 24. Washington D.C.: International Bank for Reconstruction and Development.

Lynch, James. 1954. Summary of the Public External Debt of Norway. Report No. EC 29. Washington D.C.: International Bank for Reconstruction and Development.

Lynch, James. 1954. The External Public Debt of El Salvador. Report No. EC 30. Washington D.C.: International Bank for Reconstruction and Development.

Lynch, James. 1954. The External Public Debt of Peru. Report No. EC 32. Washington D.C.: International Bank for Reconstruction and Development.

Lynch, James. 1954. Summary of the External Public Debt of the Netherlands. Report No. EC 36. Washington D.C.: International Bank for Reconstruction and Development.

Lynch, James. 1954. The External Public Debt of El Salvador. Report No. EC 37. Washington D.C.: International Bank for Reconstruction and Development.

Lynch, James. 1953. The External Debt of Italy. Report No. EC 15. Washington D.C.: International Bank for Reconstruction and Development.

Moody's. Various Years. Moody's Manual of Investments - American and Foreign. New York: Moody's Investor Service.

Organization for Economic Cooperation and Development. 1961. The Flow of Financial Resources to Countries in Course of Economic Development 1956-1959. Paris: OECD.

Organization for Economic Cooperation and Development. 1962. The Flow of Financial Resources to Countries in Course of Economic Development 1960. Paris: OECD.

Organization for Economic Cooperation and Development. 1963. The Flow of Financial Resources to Countries in Course of Economic Development 1961. Paris: OECD.

Organization for Economic Cooperation and Development. 1965. The Flow of Financial Resources to Less-Developed Countries 1956-1963. Paris: OECD.

United Nations Economic and Social Council. 1957. Financing of Economic Development Information Concerning International Economic Assistance for the Less Developed Countries. Report by the Secretary-General E/3047. New York: United Nations.

United Nations Economic and Social Council. 1958. Economic Development of Under-Developed Countries - International Economic Assistance to the Under-Developed World 1956/57. Report by the Secretary-General E/3131. New York: United Nations.

United Nations Economic and Social Council. 1961. International Economic Assistance to the Less Developed Countries. Report by the Secretary-General. New York: UN Department of Economic and Social Affairs.

\section{Secondary sources}

Behrman, Jack N., and Raymond Mikesell. 1958. Financing Free World Trade with the Sino-Soviet Bloc. Princeton Studies in International Finance 8: 1 - 268.

Bittermann, Henry J. 1973. The Refunding of International Debt. Durham: Duke University Press.

Bordo, Michael, Owen Humpage, and Anna Schwartz. 2015. The Evolution of the Federal Reserve Swap Lines since 1962. IMF Economic Review 63(2): 353 - 372. 
Eichengreen, Barry J. 1993. Reconstructing Europe's Trade and Payments : The European Payments Union. Ann Arbor: University of Michigan Press.

Inter-American Development Bank. 1966. European Financing of Latin America's Economic Development. Washington D.C.: Inter-American Development Bank.

Inter-American Development Bank. 1969. European Participation in the Financing of Latin American Development. Washington D.C.: Inter-American Development Bank.

James, Harold. 1996. International Monetary Cooperation Since Bretton Woods. New York: Oxford University Press.

Kaplan, Jacob and Günther Schleimiger. 1989. The European Payments Union: Financial Diplomacy in the 1950s. Oxford: Clarendon Press.

Kriz, Miroslav A. 1947. Postwar International Lending. Princeton Essays in International Finance 8: $1-36$.

Mikesell, Raymond. 1948. Regional Multilateral Payments Arrangements. The Quarterly Journal of Economics 62 (4): 500-518.

Mikesell, Raymond. 1962. U.S. Private and Government Investment Abroad. Eugene: University of Oregon Press.

Mikesell, Raymond. 1966. Public International Lending for Development. New York: Random House.

Schenk, Catherine. 2010. The Decline of Sterling - Managing the Retreat of an International Currency 1945 - 1992. Cambridge: Cambridge University Press.

Shonfield, Andrew, and Susan Strange, eds. 1976. International Economic Relations of the Western World 1959 - 1971. New York City: Oxford University Press.

Toniolo, Gianni. 2005. Central bank Cooperation at the Bank for International Settlements 1930 1973. Cambridge: Cambridge University Press.

Trued, Merlin Nelson and Mikesell, Raymond. 1955. Postwar Bilateral Payments Agreements. Princeton Series in International Finance 4: 1 - 132.

\section{Modern Era: 1970 - 2015}

From 1970 onwards data on official lending has been systematically collected by international organizations such as the World Bank and the OECD. Our database brings together data on official grants from the OECD's creditor reporting system (CRS) and data on bilateral loans from the World Bank's debtor reporting system (DRS). The latter is not publicly available, but has been obtained from the World Bank upon request. For multilateral lending, we make use of several different sources. Aid flows by development banks are mostly taken from the project level data published by AidData at William \& Mary (Tierney et al., 2011). In a few instances, we complement this rich data source with additional transaction-level data from annual reports of creditors. Lending by regional financial arrangements is taken from creditor organization annual reports and websites as well as from the 
database provided by Scheubel and Stracca (2016). For central bank lending, our collection of loans stems from Central bank annual reports and from existing academic research.

\section{Main Sources on bilateral creditors}

OECD. 2019. Creditor Reporting System: Aid activities. OECD International Development Statistics.

Tierney, Michael J., Daniel L. Nielson, Darren G. Hawkins, J. Timmons Roberts, Michael G. Findley, Ryan M. Powers, Bradley Parks, Sven E. Wilson, and Robert L. Hicks. 2011. More Dollars than Sense: Refining Our Knowledge of Development Finance Using AidData. World Development 39 (11): 1891-1906.

World Bank. 2017. Debtor Reporting System: Database. Request for data extract filed at http://www.worldbank.org/en/access-to-information.

\section{$\underline{\text { Main sources on multilateral creditors }}$}

Arab Monetary Fund. Various Years. Annual Report. Abu Dhabi.

Asian Infrastructure Investment Bank. 2019. Approved Projects. https://www.aiib. org/en/projects/approved/index.html.

Bank for International Settlements. Various Years. Annual Report. Basel: Bank for International Settlements.

Eurasian Fund for Stabilization and Development. 2019. "Projects: Dataset". https://efsd.eabr.org/en/projects/.

European Commission. Various Years. Report to the European Parliament and the Council on the Implementation of Macro-Financial Assistance to Third Countries. Brussels.

European Commission. Various Years. The Commission's Annual Report to the Parliament and the Council on the Borrowing and Lending Activities of the Community. Brussels: European Commission.

European Commission. 2019. Balance of Payment (BoP) Assistance. Brussels: European Commission.

European Union. Various Years. "Official Journal of the European Union.” Brussels.

European Economic Union. Various Years. Protocols on Financial and Technical Cooperation. Brussels: EUR-Lex.

Commission of the European Communities. Various Years. Annual Report from the Commission on the Implementation of Community Assistance to the Countries of East and Central Europe (PHARE). Brussels: European Economic Union.

Commission of the European Communities. Various Years. Agreements and Other Bilateral Commitments Linking the Communities with Non-Member Countries. Brussels: European Communities.

Commission of the European Communities. Various Years. Annual Report from the Commission on PHARE, Pre-Accession and Transition Instruments. Brussels: European Economic Union.

Commission of the European Communities. Various Years. General Report on Pre-Accession Assistance (PHARE - ISPA - SAPARD). Brussels: European Communities. 
European Commission. Various Years. Report from the Commission on Financial Assistance for Enlargement (IPA, PHARE, CARDS, Turkey Pre-Accession Instrument, Transition Facility). Brussels: European Commission.

European Commission. Various Years. Annual Report on the Implementation of the European Commission's External Assistance. Brussels: European Commission.

European Commission. Various Years. The TACIS Programme - Annual Report. Brussels: European Commission.

European Commission. 2009. Evaluation of the Council Regulation No 2698/2000 (MEDA II) and its Implementation - Final Report. Brussels: European Commission.

European Investment Bank. 2019. List of Financed Projects. http://www.eib.org/en/ projects/loan/list/index.htm.

European Stability Mechanism. 2019. Financial Assistance. https://www.esm. europa.eu/financialassistance.

Fondo Latinoamericano de Reservas. 2019. Historically Approved Credits. http://flar.net/.

Inter-American Development Bank. 2019. Statement of Approved Loans. https://www.iadb.org/en/idb-finance/statement-approved-loans.

New Development Bank. 2019. List of all Projects. https://www.ndb.int/projects/ list-of-all-projects/.

Scheubel, Beatrice, and Livio Stracca. 2016. Occasional Paper Series What Do We Know about the Global Financial Safety Net? Rationale, Data and Possible Evolution: Dataset. ECB Occasional Paper Series No. 177.

Tierney, Michael J., Daniel L. Nielson, Darren G. Hawkins, J. Timmons Roberts, Michael G. Findley, Ryan M. Powers, Bradley Parks, Sven E. Wilson, and Robert L. Hicks. 2011. More Dollars than Sense: Refining Our Knowledge of Development Finance Using AidData. World Development 39 (11): 1891-1906.

\section{$\underline{\text { Secondary sources }}$}

Bederman, David J. 1988. The Bank for International Settlements and the Debt Crisis: A New Role for the Central bankers' Bank? Berkeley Journal of International Law 6(1): 91 - 121.

James, Harold. 1996. International Monetary Cooperation Since Bretton Woods. New York: Oxford University Press.

James, Harold. 2012. Making the European Monetary Union. Cambridge, MA: Harvard University Press.

\section{Country-specific sources}

We cross-check and complement all of the above mentioned references by a large number of creditorspecific data sources, in particular budget plans and annual reports. We list these sources by creditor country and in alphabetic order. 
China:

Atkins, Lucas, Deborah Brautigam, Yuannan Chen, and Jyhjong Hwang. 2017. Challenges of and opportunities from the commodity price slump. CARI Economic Bulletin \#1. China Africa Research Initiative, Johns Hopkins University School of Advanced International Studies, Washington DC: CARI.

Dreher, Axel, Andreas Fuchs, Bradley Parks, Austin M. Strange, and Michael J. Tierney. 2017. Aid, China, and Growth: Evidence from a New Global Development Finance Dataset. AidData Working Paper 46.

Bartke, Wolfgang. 1975. China's Economic Aid. London: C. Hurst.

Bartke, Wolfgang. 1976. The Agreements of the People's Republic of China 1949 - 1975. Hamburg: Institut für Asienkunde.

Copper, John. 2016. China's Foreign Aid and Investment Diplomacy. 3 vols. London: Palgrave Macmillan.

Custer, Samantha, Brooke Russell, Matthew DiLorenzo, Mengfan Cheng, Siddharta Ghose, Jacob Sims, Jennifer Turner, and Harsh Desai. 2018. Ties That Bind: Quantifying China's public diplomacy and its good neighbor effect: Dataset. https://www.aiddata.org/data/chinaspublic-diplomacy-in-east-asia-and-pacific.

Gallagher, Kevin P. 2017. China's Global Energy Finance: Dataset. https://www.bu. edu/cgef/intro.

Gallagher, Kevin P., and Margaret Myers. 2019. China-Latin America Finance Database. https://www.thedialogue.org/maplist/ (accessed February 5, 2019)..

Law, Yu Fai. 1984. Chinese Foreign Aid: A Study of Its Nature and Goals with Particular Reference to the Foreign Policy and World View of the People's Republic of China, $1950-1982 . \mathrm{PhD}$ diss., University of Bielefeld.

Lin, Teh-chang. 1993. The foreign aid policy of the People's Republic of China: A theoretical analysis. PhD diss., Northern Illinois University.

Lowy Institute. 2018. Pacific Aid Map. https://pacificaidmap.lowyinstitute.org/.

Lowy Institute. 2018. Chinese Aid in the Pacific. https://chineseaidmap.lowy institute.org/.

France:

Duvergier, J. B., ed. Various Years. Collection Complete des Lois, Decrets, Ordonnances, Reglemens et Avis du Conseil-d'Etat. Paris: Bibliotheque Nationale de France.

Hayter, Theresa. 1966. French Aid. London: Overseas Development Institute.

Journal Officiel de la Republique Francais. Various Years. Lois et Decrets. Paris: Bibliotheque Nationale de France.

Le Ministre Secretaire D'Etat des Finances. Various Years. Comptes Rendus par les Ministres. Paris: L'Imprimerie Royale.

Ministere du Commerce, de l'Industrie, des Postes et des Telegraphes. Various Years. Annuaire Statistique. Paris: Bibliotheque Nationale de France.

Ministere de l'Europe et des Affaires etrangeres. 2019. Traites et accords de la France. https://basedoc.diplomatie.gouv.fr/.

Plessis, Alain. 1998. Histoires de La Banque de France. Paris: Albin Michel. 
Germany:

Cholet, Julia. 2011. Der Etat des Deutschen Reiches in der Bismarckzeit. Berlin: Berliner Wissenschaftsverlag.

Kaiserliches Statistisches Amt. Various Years. Statistisches Jahrbuch für das Deutsche Reich. Berlin: Kaiserliches Statistisches Amt.

Deutsche Bundesbank. Various Years. Geschäftsbericht. Frankfurt a. M.: Deutsche Bundesbank.

Kruse-Rodenacker, Albrecht, Horst Dumke, and Niklas von Götz. 1970. Kapitalhilfe: Probleme und Aufgaben. Berlin: Duncker \& Humblot.

Reichstag des Deutschen Kaiserreichs. Various Years. Verhandlungen des Deutschen Reichstags. www.reichstagsprotokolle.de (accessed February 5, 2019).

Schmidt, Heide-Irene. 2003. Pushed to the Front: The Foreign Assistance Policy of the Federal Republic of Germany 1958-1971. Contemporary European History 12(4): 473-507.

Schnee, Heinrich, ed. 1920. Deutsches Kolonial-Lexikon. Leipzig: Quelle \& Meyer.

White, John. 1965. German Aid - A Survey of the Sources, policies and Structure. London: Overseas Development Institute.

United Kingdom:

Bank of England. Various Years. Annual Report. London: Bank of England.

Clapham, J. H. 1945. The Bank of England: A History. London: The Macmillan Company.

Mackintosh, Athole and Andrzej Krassowski. 1963. British Aid. London: Overseas Development Institute.

Ministry of Overseas Development. 1966. Overseas Development - The Work in Hand. London: Ministry of Overseas Development

Scholes, Teophilus. 1899. The British Empire and Alliances: or, Britain's Duty to her Colonies and Subject Races. London: E. Stock.

UK House of Commons. Various Years. Appropriation Accounts. UK House of Commons Parliamentary Papers.

UK House of Commons. Various Years. Colonial Development Fund Accounts. UK House of Commons Parliamentary Papers.

UK House of Commons. Various Years. Finance Accounts of the United Kingdom of Great Britain and Ireland for the Financial Year. UK House of Commons Parliamentary Papers.

UK House of Commons. Various Years. UK Treaty Series. UK House of Commons Parliamentary Papers.

UK Foreign Office. Various Years. British and Foreign State Papers. London: Her Majesty's Stationary Office.

United States:

Bevans, Charles. Various Years. Treaties and Other International Agreements of the United States of America. Washington D.C.: Department of State.

Export-Import Bank of Washington. Various Years. Annual Report. Washington D.C.: Export-Import Bank. 
Export-Import Bank of Washington. Various Years. Report to Congress. Washington D.C.: ExportImport Bank.

Federal Reserve System. Various Years. Federal Reserve Bulletin. Washington D.C.: Federal Reserve.

Trundle, Sidney. 1950. The Export-Import Bank of Washington - Its Origins, Operations and Relationships with Other Governmental Agencies 1934 - 1950. PhD dissertation, Rutgers University.

US Agency for International Development. 2019. Greenbook - U.S. Overseas Loans and Grants. https://explorer.usaid.gov/reports.html/tab-greenbook.

US Department of Commerce. 1952. Foreign Aid by the United States Government 1940 - 1951. Washington D.C.: US Department of Commerce.

US Department of State. Various Years. Report to Congress on Lend-Lease Operations. Washington D.C.: US Department of State.

US Treasury. Various Years. Annual Report of the Secretary of the Treasury on the State of the Finances. Washington D.C.: US Treasury.

US Treasury. 2019. Exchange Stabilization Fund - History of Credit Operations. https://www.treasury.gov/resource-center/international/ESF/Pages/history-index.aspx.

Williams, Benjamin. 1939. Foreign Loan Policy of the United States since 1933. New York City: Council for Foreign Relations.

\section{Soviet Union and COMECON Countries:}

Bach, Quintin. 2003. Soviet Aid to the Third World: The Facts and Figures. Lewes: Book Guild.

Central Intelligence Agency. Various Years. Communist Aid to Non-Communist Less Developed Countries. Langley, VA: Central Intelligence Agency.

Central Intelligence Agency. Various Years. Soviet Economic Assistance to the Sino-Soviet Bloc. Langley, VA: Central Intelligence Agency.

Shapiro, Leonard, ed. Various Years. Soviet Treaty Series. A Collection of Bilateral Treaties, Agreements and Conventions, Concluded between the Soviet Union and Foreign Powers. Washington D.C.: Georgetown University Press.

Triska, Jan and Robert M. Slusser. 1962. The Theory, Law and Policy of Soviet Treaties. Stanford: Stanford University Press.

Walters, Robert. 1966. Soviet Economic Aid to Cuba: 1959 - 1964. International Affairs 42 (1): 74-86.

Other creditor countries:

Boogaerde, Pierre. 1990. The Composition and Distribution of Financial Assistance from Arab Countries and Arab Regional Institutions. IMF Working Paper WP/90/67.

Takagi, Shinji. 1995. From Recipient to Donor: Japan's Official Aid Flows, 1945 to 1990 and Beyond. Princeton Essays in International Finance 164: 1 - 50.

Kuwait Fund for Arab Economic Development. Various Years. Annual Report. Kuwait City: Kuwait Fund. 


\section{Coverage of multilateral creditors}

This section provides an overview on the multilateral creditor organizations that are covered in our international official lending database as well as the coding sources. The table distinguishes between (i) organizations that have global coverage, (ii) stability arrangements that have regional membership and specialize in the provision of balance of payments support, and (iii) regional development banks that specialize in the provision of development finance to certain groups of countries. Our data collection for the BIS and UN agencies is still ongoing.

Table AI1. Coverage of multilateral creditors

\begin{tabular}{|c|c|c|}
\hline Global organizations & Time coverage & Main data sources \\
\hline Bank for International Settlements & $1930-2015$ & $\begin{array}{l}\text { BIS Annual Reports } \\
\text { BIS Archive }\end{array}$ \\
\hline International Monetary Fund & $1944-2015$ & $\begin{array}{l}\text { Reinhart \& Trebesch (2016) } \\
\text { IMF Annual Reports }\end{array}$ \\
\hline International Bank for Reconstruction and Development (IBRD) & $1947-2015$ & $\begin{array}{l}\text { IBRD Statement of Loans } \\
\text { (available online) }\end{array}$ \\
\hline International Development Association (IDA) & $1961-2015$ & $\begin{array}{l}\text { IDA Statement of Loans } \\
\text { (available online) }\end{array}$ \\
\hline League of Nations & $1920-1939$ & $\begin{array}{l}\text { Moody's Investment Manual } \\
\text { Flores and Decorzant (2015) }\end{array}$ \\
\hline United Nations Development Programme (UNDP) & $1979-2015$ & Annual Reports \\
\hline $\begin{array}{l}\text { United Nations International Children's Emergency Fund } \\
\text { (UNICEF) }\end{array}$ & $1979-2015$ & Annual Reports \\
\hline $\begin{array}{l}\text { United Nations High Commisioner for Refugees } \\
\text { (UNHCR) }\end{array}$ & $2005-2015$ & Annual Reports \\
\hline $\begin{array}{l}\text { United Nations Central Emergency Relief Fund } \\
\text { (UNCERF) }\end{array}$ & $2005-2015$ & Annual Reports \\
\hline
\end{tabular}


Regional Stability Arrangements

Andean Reserve Fund

Arabic Monetary Fund

BRICS Contingent Reserves Agreement

Chiang Mai Initiative (CMI)

Chiang Mai Initiative Multilateralisation (CMIM)

Eurasian Fund for Stability and Development

European Payments Union

European Monetary Fund (EMA)

European MTFA Facility

European Community Loan Mechanism

European Balance of Payments Facility

European Financial Stability Mechanism

European Financial Stability Facility

European Stability Mechanism

Latin American Reserve Fund

(Fondo Latino Americano de Reservas - FLAR)
$1978-1989$

$1977-2015$

$2014-2015$

$2000-2009$

$2009-2015$

$2010-2015$

$1950-1958$

$1958-1973$

$1971-1988$

$1975-1988$

$1988-2015$

$2010-2015$

$2010-2015$

$2012-2015$

$1989-2017$
Main data sources

FLAR Website

FLAR Annual Reports

AMF Annual Reports

Establishment Treaty

(not activated)

Central Bank websites (not activated)

Central Bank websites

(not activated)

EFSD Annual Repots

BIS Annual Reports

BIS Annual Reports

Official Journal of the EU

Official Journal of the EU

Official Journal of the EU

ESM Website

ESM Website

ESM Website

FLAR Website 
Development Banks and other regional creditors

African Development Bank (AFDB)

African Development Fund (AFDF)

Andean Development Corporation (CAD)

Arab Bank for Economic

Development in Africa (BADEA)

Arab Fund for Economic and Social Development (AFESD)

Asian Development Bank (AsDB)

Asian Infrastructure Investment Bank (AIIB)

Caribbean Development Bank (CDB)

Council of Europe

European Bank of Reconstruction and Development (EBRD)

Euratom

European Coal and Steel Community (ECSC)

European Development Fund

European Investment Bank

European Union PHARE

European Union IPA

Inter-American Development

Bank (IADB)

International Fund for

Agricultural Development

Time coverage

$1967-2015$

1974 - 2015

$1988-2015$

$1975-2015$

1974 - 2015

$1968-2015$

$2015-2015$

$1970-2015$

$1958-2015$

$1991-2015$

$1958-1967$

$1951-1967$

$1973-2015$

$1959-2015$

1989 - 2007

$2007-2015$

$1959-2015$

$1977-2015$
Main data sources

AidData

OECD CRS

AidData

OECD CRS

AidData

Annual Reports

AidData

OECD CRS

AidData

OECD CRS

AidData

Annual Reports

Website

AidData

Annual Reports

Annual Reports

AidData

OECD CRS

Official Journal of the EEC Moody's Investor Manual

Official Journal of the EEC

Moody's Investor Manual

AidData

OECD CRS

EIB Project History

Website

Annual Reports

Annual Reports

AidData

Annual Reports

AidData

DRS 
Islamic Development Bank

(IsDB)

New Development Bank

Nordic Development Fund

North American Development Bank

OPEC Fund for International

Development (OFID)

Organization for Security and Cooperation in Europe (OSCE)

\begin{tabular}{|c|c|}
\hline $1976-2015$ & $\begin{array}{l}\text { AidData } \\
\text { OECD CRS }\end{array}$ \\
\hline $2014-2015$ & Website \\
\hline $1977-2015$ & $\begin{array}{l}\text { AidData } \\
\text { OECD CRS }\end{array}$ \\
\hline $1996-2015$ & $\begin{array}{l}\text { AidData } \\
\text { Annual Reports }\end{array}$ \\
\hline $1976-2015$ & $\begin{array}{l}\text { AidData } \\
\text { OECD CRS }\end{array}$ \\
\hline $2005-2015$ & $\begin{array}{l}\text { AidData } \\
\text { OECD CRS }\end{array}$ \\
\hline
\end{tabular}

